OPEN ACCESS

Edited by:

Ying $X u$,

University at Buffalo, United States

Reviewed by:

Tong Li,

Johns Hopkins University,

United States

Istvan Jozsef Merchenthaler, University of Maryland, Baltimore,

United States

*Correspondence:

Donghui Zhu

Donghui.Zhu@stonybrook.edu

Received: 04 June 2021

Accepted: 13 August 2021

Published: 08 September 2021

Citation:

Akhter F, Persaud A, Zaokari Y, Zhao Z and Zhu D (2021) Vascular

Dementia and Underlying Sex

Differences.

Front. Aging Neurosci. 13:720715.

doi: 10.3389/fnagi.2021.720715

\section{Vascular Dementia and Underlying Sex Differences}

\author{
Firoz Akhter' ${ }^{1}$ Alicia Persaud ${ }^{1}$, Younis Zaokari', Zhen Zhao ${ }^{2}$ and Donghui Zhu ${ }^{1,3 *}$ \\ 1 Department of Biomedical Engineering, Stony Brook University, Stony Brook, NY, United States, ${ }^{2}$ Department of Physiology \\ and Neuroscience, Zilkha Neurogenetic Institute, Keck School of Medicine, University of Southern California, Los Angeles, \\ CA, United States, ${ }^{3}$ Neuroscience Graduate Program, Renaissance School of Medicine, Stony Brook University, Stony \\ Brook, NY, United States
}

Vascular dementia $(\mathrm{VaD})$ is the second most common form of dementia after Alzheimer's disease (AD); where Alzheimer's accounts for 60-70\% of cases of dementia and VaD accounts for $20 \%$ of all dementia cases. $\mathrm{VaD}$ is defined as a reduced or lack of blood flow to the brain that causes dementia. $\mathrm{VaD}$ is also known occasionally as vascular contributions to cognitive impairment and dementia (VCID) or multi-infarct dementia (MID). VCID is the condition arising from stroke and other vascular brain injuries that cause significant changes to memory, thinking, and behavior, and $\mathrm{VaD}$ is the most severe stage while MID is produced by the synergistic effects caused by multiple mini strokes in the brain irrespective of specific location or volume. There are also subtle differences in the presentation of $\mathrm{VaD}$ in males and females, but they are often overlooked. Since 1672 when the first case of $\mathrm{VaD}$ was reported until now, sex and gender differences have had little to no research done when it comes to the umbrella term of dementia in general. This review summarizes the fundamentals of $\mathrm{VaD}$ followed by a focus on the differences between sex and gender when an individual is diagnosed. In addition, we provide critical evidence concerning sex and gender differences with a few of the main risk factors of $\mathrm{VaD}$ including pre-existing health conditions and family history, gene variants, aging, hormone fluctuations, and environmental risk factors. Additionally, the pharmaceutical treatments and possible mitigation of risk factors is explored.

Keywords: vascular dementia, Alzheimer's disease, sex, gender, multi-infarct dementia

\section{INTRODUCTION}

Vascular dementia $(\mathrm{VaD})$, a heterogeneous group of brain disorders is the next most common form of dementia following Alzheimer's disease (AD) and accounts for at least $20 \%$ of dementia cases (Román, 2003; Korczyn et al., 2012). VaD is caused by a blocked or reduced blood flow to the brain which will deprive neurons of critical nutrients (Vijayan and Reddy, 2016). This deprivation eventually causes the neurons to die, and the brain tissue starts to shrink. Some common contributors to this kind of dementia include stroke, cardiovascular disease, diabetes, hyperlipidemia, and hypertension (Song et al., 2014).

Vascular cognitive impairment (VCI) is a term that encompasses a continuum of cognitive disorders with cerebrovascular pathology contribution, ranging from mild cognitive impairment to $\mathrm{VaD}$ (Nguyen et al., 2021). As a result, $\mathrm{VCI}$ and $\mathrm{VaD}$ constitute an intriguing junction of 
cardiovascular disease (CVD), and neurodegenerative disorders, like $\mathrm{AD}$, are a growing topic of research in recent years. Even though VCI and $\mathrm{VaD}$ research has identified a variety of causes and explanations for disease development, many aspects remain unknown, particularly sex differences in VCI (e.g., epidemiology), which are lacking in comparison to those available for CVD and $\mathrm{AD}$.

\section{History of Vascular Dementia (VaD)}

The root meaning of the word dementia came from the Latin word demons which means "Without mind." The first case of $\mathrm{VaD}$ was reported in 1672 by Thomas Willis in his book De Anima Brutorum (Román, 2003). After the recognizing of the differences between hemorrhage and ischemic stroke, Bayle discovered that apoplexy was the obstruction of the arteries with effusion of blood in such small amounts because of the failure of the blood influx to the brain (Engelhardt, 2017). Apoplexy is unconsciousness and/or incapacitation resulting from a cerebral hemorrhage or stroke. Later, apoplexy was considered the cause of brain congestion or cerebral hyperemia in most of the 18th and early 19th centuries. The year 1894 is considered to be the beginning of the modern history of $\mathrm{VaD}$ due to Otto Binswanger and Alois Alzheimer, who were the first to separate the forms of dementia from neurosyphilis and recognize a heterogeneous $\mathrm{VaD}$ (Yang et al., 2016). In 1910 Emile Kraepelin closely observed the concept of Otto Binswanger and Alois Alzheimer with a different description for $\mathrm{VaD}$ as arteriosclerotic dementia or cerebral arteriosclerosis (Román, 2003). For 70 years after Kraepelin's description, the synonym for his description of $\mathrm{VaD}$ was called senile dementia. Hachinski et al. (1974) emphasized that vascular disease was responsible for dementia, via the occurrence of small or large cerebral infarcts; the term Multi Infract dementia (MID) was to be used synonymously with VaD. In 1995 a proposal was made to the National Institutes of Health that the broader term $\mathrm{VaD}$ could be changed to the new name Vascular Cognitive Impairment.

\section{Symptoms, Risk Factors, Characteristic Features, and Subtypes of VaD}

The symptoms of $\mathrm{VaD}$ differ depending on which part of the brain the vessels and blood flow are obstructed (Venkat et al., 2015). However, the common indications might appear as disorientation, difficulty thinking, understanding, inability to create new memories, agitation, or behavioral symptoms (Kalaria, 2016). Moreover, VaD symptoms may be most obvious when they happen soon after a major stroke, and they can gradually develop (Dichgans and Leys, 2017). Figure 1 shows some of the risk factors, characteristic features, and subtypes associated with VaD.

The risk factors help perpetuate the occurrence of the $\mathrm{VaD}$. Strokes that block a brain artery usually cause a range of symptoms like cognitive decline, neurological deficits, and further severe cardiovascular incidents that may include vascular dementia (Shabir et al., 2018). When VaD begins, it can be classified into various subtypes that are typically related to the root cause of the VaD (Rockwood et al., 1999). Stroke, multiinfarct, and subcortical dementia refer to the vascular events

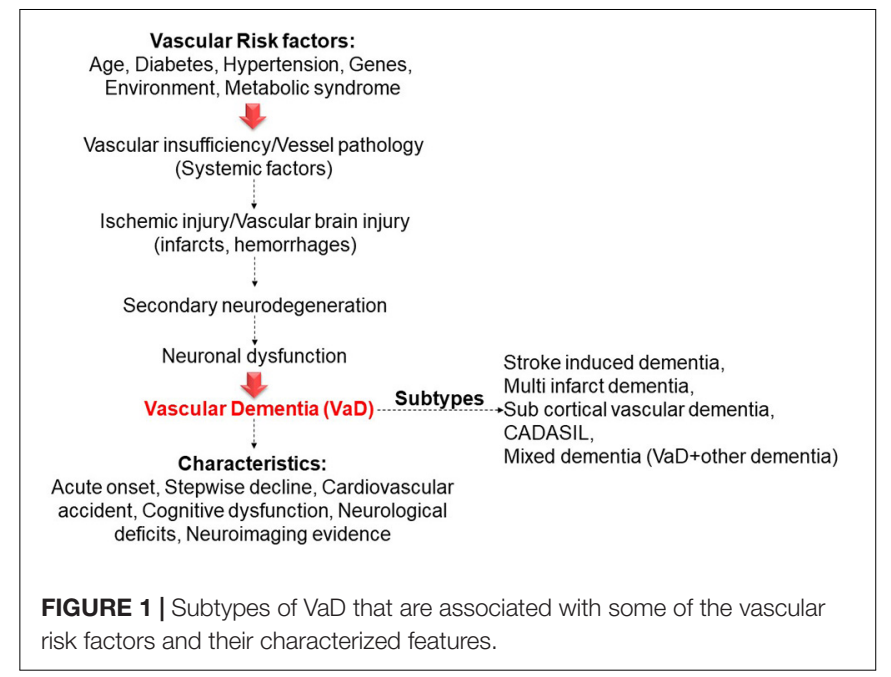

leading to dementia (Kalaria and Erkinjuntti, 2006). CADASIL refers to a subtype of $\mathrm{VaD}$, in which a specific gene variant must be present (Benisty et al., 2008). This variant whilst mixed with dementia causes a rare disease subtype that refers to the presence of multiple forms of dementia including the presence of vascular events (Benisty et al., 2008). In CADASIL, migraine with aura is more frequent in women and, stroke is more frequent in men before menopause (Gunda et al., 2012). After this age limit, the difference appears to vanish, however, men in the late stages of the disease may experience more cognitive impairment and cerebral atrophy.

Dementia is a consequence and a risk factor for stroke and $\mathrm{VaD}$. Stroke is one of the primary causes of disability, and having a stroke doubles your risk of developing VaD (Vijayan and Reddy, 2016). Lower education, older age, diabetes mellitus, myocardial infarction, atrial fibrillation, epileptic seizures, sepsis, cardiac arrhythmias, congestive heart failure, global cerebral atrophy, and medial temporal lobe atrophy, and white matter changes have all been linked to an increased risk of dementia after a stroke (Pinkston et al., 2009). Post-stroke depression is another risk factor for $\mathrm{VaD}$, which is more common in women than in men (Pendlebury and Rothwell, 2009). Female sex, medial temporal lobe atrophy, and a family history of dementia are all better predictors of pre-stroke dementia than post-stroke dementia (Podcasy and Epperson, 2016). Pre-stroke dementia could be a symptom or cause of a fundamental degenerative condition that makes vascular events more likely (Glader et al., 2003).

Multi-infarct dementia is a type of $\mathrm{VaD}$, occurs when a series of minor strokes triggers a loss of brain function (Al-Qazzaz et al., 2014). A stroke, or brain infarct, occurs when the blood flow to any part of the brain is disrupted or blocked. Blood supplies oxygen to the brain, and brain tissue dies quickly without it. Memory and cognitive function loss can occur because of MID, as well as psychosocial issues. MID generally occurs in people aged 55 to 75 years and is more common in men than women (McKay and Counts, 2017). Medical conditions and lifestyle that increase the risk of MID include atrial fibrillation, rapid heartbeat, previous strokes, heart failure, cognitive decline before a stroke, 
high blood pressure, diabetes, atherosclerosis, or hardening of the arteries, smoking, alcohol, a low level of education, a poor diet, little to no physical activity (Lechner and Bertha, 1991).

Subcortical VaD is the subtype that has attracted the most interest among all the potential VaD subtypes (Wallin et al., 2003). Lacunar infarcts and ischemic white-matter lesions with demyelination and axon loss are the most common brain lesions in this kind of $\mathrm{VaD}$. The primary cause is an injury to the penetrating arteries vessel walls (Kalaria, 2016). Multiple vascular problems, such as arterial hypertension, diabetes, and ischemic heart disease, are common in patients with subcortical VaD. Impairment goal formulation, starting, planning, and organizing are among the clinical signs (O’Brien and Thomas, 2015). Cerebrovascular white matter lesions are associated with stroke, cognitive decline, dementia, and death in a meta-analysis of longitudinal studies (Debette and Markus, 2010). These lesions correlate with advancing age, female gender, and vascular risk factors, including hypertension, diabetes mellitus, smoking, and lower income (Tomimoto, 2011). Another study was unable to find significant differences in the role of sex in subcortical $\mathrm{VaD}$ cases (Choi et al., 2020).

Cognitive impairment caused by numerous central nervous system (CNS) disorders are referred to as mixed dementia. A combination of $\mathrm{AD}$ pathologies such as amyloid deposits and tau tangles-and vascular impairment, such as numerous microbleeds or infarcts, is the most common cause of this disease (Jellinger, 2004). Rendering to vascular theory, chronic diseases (hypertension, diabetes mellitus, cardiac disease, dyslipidemia, and obesity) and the sedentary lifestyle produce numerous vascular changes, which generate vascular atrophy of the vascular terminations, as well as a reduction in the number of terminal blood vessels (Zekry et al., 2002). These alterations affect the cerebral microvasculature and diminish the cerebral blood flow, which is mainly observed in untreated hypertensive patients and those treated sporadically or inadequately (Hanyu, 2012). It is generally accepted that vascular dementia and mixed dementias occur more frequently in males, with rates of 31 vs. $25 \%$ in females (Podcasy and Epperson, 2016).

\section{Diagnosis, and Current Treatment}

The diagnostic tools for $\mathrm{VaD}$ vary on the diagnosis of the patients. A person suspected of having $\mathrm{VaD}$ will generally have a brain scan to look for any changes that have taken place in the brain. A scan such as Computerized tomography (CT) or magnetic resonance imaging (MRI) is also common to visualize brain function and may rule out a blockage or build-up of fluid inside the brain (van Straaten et al., 2004). Carotid ultrasound is used to determine whether the carotid artery shows any signs of narrowing because of plaque deposits or structural issues causing reduced blood flow to the brain (Malojcic et al., 2017). Neurological exams for reflexes, muscle tone and strength, are used as well as qualitative exams on comparing strength on one side of the body with the other side, assessing ability to get up from a chair and walk across the room, the intensity of touch, sight, coordination, and balance. Neuropsychological tests are also used to examine the ability to speak, write and understand language, work with numbers, learn and remember information, develop a plan of attack/solve a problem, and respond effectively to hypothetical situations (Pimentel, 2009).

In terms of treatments, the medical field lacks actual drugs that are fully approved by the FDA. However, there are clinical trials for drugs that treat $\mathrm{AD}$ symptoms which can also be offered to patients with $\mathrm{VaD}$ as well (Huang et al., 2020). With regards to anti-dementia therapeutics, there are no specific drugs approved for $\mathrm{VaD}$ treatment. The cholinesterase inhibitors, and the NMDA (the N-methyl-Daspartate receptor) antagonist, are the only medications currently licensed for $\mathrm{AD}$ treatment, have been found to show some cognitive improvements in mild to moderately advanced $\mathrm{VaD}$ (Kandiah et al., 2017; Yaowaluk et al., 2019; Jian et al., 2020). Memantine belongs to the aminoadamantane chemical class and is structurally like amantadine, an anti-Parkinson and antiviral drug. Memantine has been tested in a study that included 815 subjects with mild to moderately advanced $\mathrm{VaD}$ (Baskys and Hou, 2007). Treatment with $20 \mathrm{mg}$ /day dose or placebo lasted 28 weeks. Data analysis showed a significant improvement in cognitive function, measured as ADAS-cog (Alzheimer's Disease Assessment Scale-cognitive subscale), from baseline, over placebo. In a recent study (Arrigo et al., 1990), 56 patients with dementia and cerebrovascular illness were randomized to receive either acetyl-L-carnitine (ALC) $1.5 \mathrm{~g} /$ day or placebo for 28 weeks in a multicenter, double-blind, placebocontrolled clinical trial. The individuals' scores on the Montreal Cognitive Assessment improved dramatically after taking ALC, particularly in the attention and language subitems. However, it's difficult to believe that the study was solely focused on $\mathrm{VaD}$ because the patients were already on donepezil, implying that a significant proportion of them may have been affected by $\mathrm{AD}$ or mixed dementia (Pennisi et al., 2020). A small but statistically significant improvement was found on the NOSGER (Nurses Observational Scale for Geriatric Patients) disturbing behavior scale. Additionally, there have been attempts to use similar medicines that treat underlying causes of VaD. For example, in a small study hypertension medicines had a positive correlation with $\mathrm{VaD}$ risk reduction compared to subjects with similar risk factors but were without the antihypertensive (Iulita and Girouard, 2017). These include tablets to reduce blood pressure, prevent blood clots and lower cholesterol. Sometimes if treated early blood vessels can repair and slow the rate at which VaD progresses and might prevent further development of symptoms (Lee, 2011). A 5-year follow-up study on a community sample of 1617 African Americans demonstrated that the use of medications that mediate vascular risk factors (antihypertensive drugs, anti-hyperlipidemic, and antidiabetic drugs) reduced the risk of incident dementia by $40 \%$ (Kennelly et al., 2009). Lastly, some research also suggests that after a big vascular event like a stroke, preventative measures are vital for mitigating the risk of developing VaD (Vijayan and Reddy, 2016; Hachinski et al., 2019).

\section{CLINICAL PRESENTATION OF VaD}

Since 2011, published studies are, not only in VaD but in some dementias and other cognitive disorders as well. However, 
a critical review of the more recent trials and the effects of sex/gender on $\mathrm{VaD}$ is still lacking. The purpose of this clinical presentation is to provide an update on the existing studies dealing with sex and gender in $\mathrm{VaD}$ to obtain a clear and comprehensive overview of all clinical benefits, potential effects of sex/gender, limitations, and main outcomes in the management of these patients.

\section{Data Source and Selection}

A Medline (PubMed)-based literature review was performed by using the following search terms, in different combinations: "Vascular dementia," "Vascular cognitive impairment," "Vascular cognitive impairment and dementia," "Arteriosclerotic dementia," "multi-infarct dementia," "vascular contributions to cognitive impairment and dementia," "sex," and "gender." The studies had to include individuals with a clinical diagnosis of any type of Vascular dementia in relation to sex or gender and severity according to the internationally accepted guidelines or diagnostic criteria. Duplicated entries, studies on physiological brain aging or diseases different from VaD, VCI, or VCID, works on animals or cell cultures, studies not reporting the statistical analysis, non-English written papers, publications that are not research studies (i.e., abstracts, letters, commentaries, editorials, reviews, etc.), conference, meeting proceedings, or any other paper not published in international peer-reviewed journals, study protocols, personal communications, or unpublished data, as well as any other study that did not fit with the scope of this review were excluded. Articles listed in the references were also reviewed in search of more data.

\section{Results}

A total of 113 results were originally retrieved and screened. Of these, six publications were selected according to the inclusion and exclusion criteria. The examination of the references detected other five studies, whose analysis identified one additional paper fitting the purpose of this review. Therefore, a total of seven papers were eventually included in the qualitative synthesis (Figure 2), and the main findings are summarized in Table 1 (Vinciguerra et al., 2020).

\section{GENERAL CAUSES AND RISKS FOR VaD}

Generally, the common causes of $\mathrm{VaD}$ are environmental and pathophysiological that affecting the brain vessels, leading to a reduction of supplies like nutrition and oxygen to the brain (Kalaria, 2016; Killin et al., 2016; Caruso et al., 2019). Therefore, some of the risk factors for $\mathrm{VaD}$ coexist with the increased risk of stroke, heart disease, aging, atherosclerosis, high cholesterol, high blood pressure, diabetes, genetics, smoking, obesity, and atrial fibrillation. VaD progresses over time and targets cognitive abilities in the brain (Kalaria et al., 2016). This actively illustrates some of the neurological and behavioral changes that patients with $\mathrm{VaD}$ may experience such as memory impairment, loss of executive function (like decreased ability to plan), reasoning and organized thoughts and behaviors. Several regulatory mechanisms and cellular

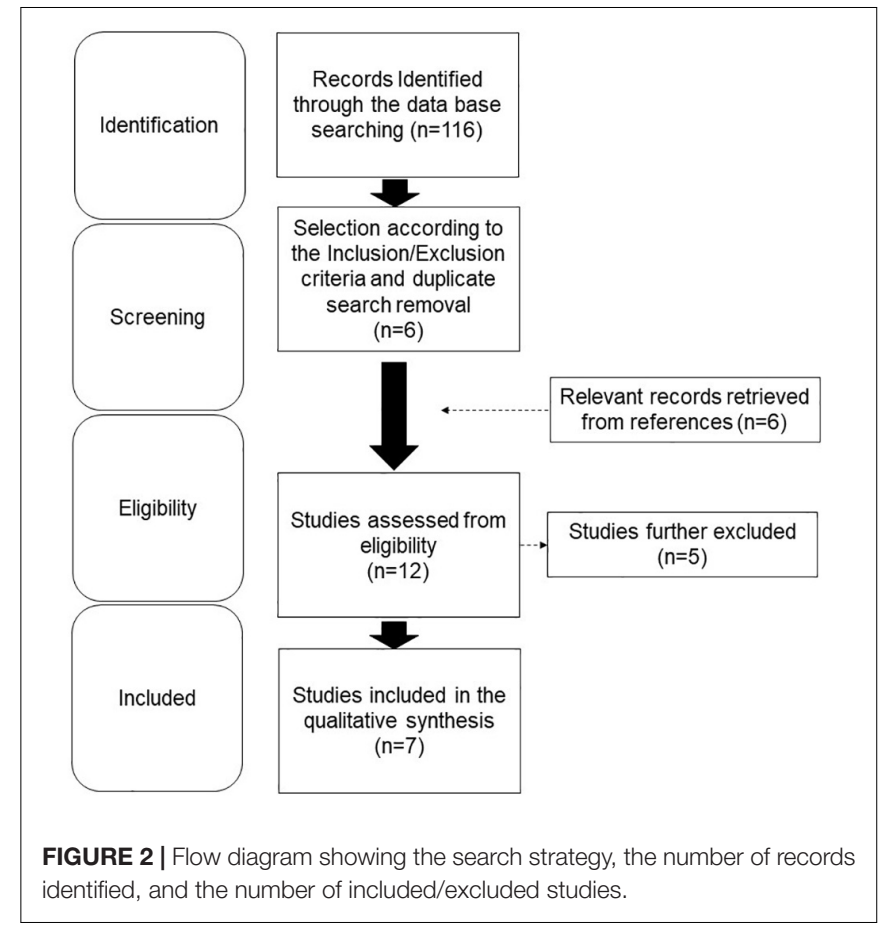

signaling are thought to play a role in VCI and VaD, including oxidative stress, neuroinflammation, endothelial dysfunction, hypoperfusion, blood-brain barrier (BBB) disruption, cortical hyperexcitability, and neurotransmitter imbalance (Vinciguerra et al., 2020). In addition, serological markers that can help in the diagnosis of $\mathrm{VaD}$ have been discovered in several investigations. Pro-inflammatory metabolites (such NO-related compounds), cytokines (including IL-1, TNF- $\alpha$, IFN- $\gamma$, IL-4, IL-5, IL-8, G-CSF, and MIP-1b), and endothelial dysfunction indicators (like homocysteine) have all been reported to be elevated in $\mathrm{VaD}$ patients (Schmitz et al., 2015).

Moreover, common causes and risk factors of $\mathrm{VaD}$ change from one sex to another. For example, males have appeared to be slightly at a higher risk of getting $\mathrm{VaD}$ than females at a younger age, but women over the age of 85-90 have been shown to have a higher occurrence (Lucca et al., 2020). Therefore, females have high-risk factors that may be associated with preeclampsia, menopause and poorly timed hormone replacement therapy. Additionally, females have a higher risk of $\mathrm{VaD}$ with the presence of diabetes, obesity, and hypertension more than males (Gannon et al., 2019). On the other hand, males have a higher risk with the presence of hyperlipidemia, myocardial infarction, and heart disease like stroke, and heart attack (Skoog, 1994).

\section{SEX-SPECIFIC DIFFERENCES IN VaD}

Increasing evidence suggests that sex factors may play an important role in the pathogenesis of diseases, including cardiovascular disease and dementia. Sex differences in prevalence also depend on dementia subtypes, such as $\mathrm{AD}$, VaD, Lewy body dementia (LBD), and Parkinson's dementia 
TABLE 1 | Studies on vascular dementia $(\mathrm{VaD})$ in relation with sex or gender.

\begin{tabular}{|c|c|c|c|c|c|c|c|c|}
\hline Sex & $\begin{array}{l}\text { Age in years } \\
\text { (Average age) }\end{array}$ & $\begin{array}{l}\text { Diagnostic } \\
\text { criteria }\end{array}$ & $\begin{array}{l}\text { Education and } \\
\text { marital status }\end{array}$ & $\begin{array}{l}\text { Medical risk } \\
\text { factors }\end{array}$ & Subjects & Key findings & $\begin{array}{l}\text { Adjusted } \\
\text { variables }\end{array}$ & References \\
\hline Male & $\geq 55.0$ (80.3) & $\begin{array}{l}\text { MMSE, } \\
\text { GMS-B, } \\
\text { AGECAT, HAS, } \\
\text { Katz's bADL's, } \\
\text { IADL's, } \\
\text { EURODEM, } \\
\text { Risk Factors } \\
\text { Questionnaire. }\end{array}$ & $\begin{array}{l}\text { Primary school, } \\
\text { High school or } \\
\text { higher. } \\
\text { Single, married or } \\
\text { living as a couple, } \\
\text { divorced, or } \\
\text { separated, or } \\
\text { widowed }\end{array}$ & $\begin{array}{l}\text { Vascular disease } \\
\text { (angina, myocardial } \\
\text { infarct, and/or stroke), } \\
\text { diabetes, hypertension, } \\
\text { health status, } \\
\text { depression, cognitive } \\
\text { status, vascular risk } \\
\text { factors (smoking, statin } \\
\text { use, body mass index, } \\
\text { and alcohol intake) }\end{array}$ & 1,828 & $\begin{array}{l}\text { In men, but not in } \\
\text { women, risk of } \mathrm{VaD} \\
\text { was higher among } \\
\text { individuals with } \\
\text { anxiety }\end{array}$ & No description & $\begin{array}{l}\text { Santabárbara et al., } \\
2020\end{array}$ \\
\hline Female & $\geq 55.0(79.8)$ & & & & 2,229 & & & \\
\hline Male & $\begin{array}{l}\geq 65.0 \text { (no average } \\
\text { age description } \\
\text { about male) }\end{array}$ & $\begin{array}{l}\text { MMSE, GMS, } \\
\text { CAMCOG, } \\
\text { DSM-III-R }\end{array}$ & - & $\begin{array}{l}\text { Hypercholesterolemia, } \\
\text { hypertension, or } \\
\text { smoking, } \\
\text { apolipoprotein E4 allele }\end{array}$ & 12,270 & $\begin{array}{l}\text { There was no } \\
\text { difference by sex in } \\
\text { the cumulative risk } \\
\text { of vascular } \\
\text { dementia. The risk } \\
\text { for a } 65 \text {-year-old } \\
\text { woman to develop } \\
\text { vascular dementia } \\
\text { at the age of } \\
95 \text { years was } 0.040 \\
\text { compared with } \\
0.041 \text { for a man. }\end{array}$ & $\begin{array}{l}\text { Age, the square } \\
\text { term of age, } \\
\text { dummy variables } \\
\text { for study, smoking, } \\
\text { education, } \\
\text { self-reported } \\
\text { myocardial } \\
\text { infarction, and } \\
\text { stroke. }\end{array}$ & $\begin{array}{l}\text { Andersen et al., } \\
1999\end{array}$ \\
\hline Female & $\begin{array}{l}\geq 65.0 \text { (no average } \\
\text { age description } \\
\text { about female) }\end{array}$ & & & & 16,497 & & & \\
\hline Male & $\geq 60.0(70.1)$ & $\begin{array}{l}\text { NINDS- AIREN, } \\
\text { CASI, IQCODE }\end{array}$ & $\begin{array}{l}\text { Less education } \\
\text { ( }<7 \text { Years), Higher } \\
\text { education } \\
\text { ( } \geq 7 \text { Years) }\end{array}$ & $\begin{array}{l}\text { Age, sex, obesity, } \\
\text { hypertension, diabetes, } \\
\text { stroke, drinking, } \\
\text { smoking, education }\end{array}$ & 845 & $\begin{array}{l}\text { Sex and a sex-age } \\
\text { interaction showed } \\
\text { significant effects } \\
\text { with respect to } \\
\text { probable VaD, but } \\
\text { not to probable or } \\
\text { possible AD or } \\
\text { possible } \mathrm{VaD} \text {. }\end{array}$ & No description & $\begin{array}{l}\text { Yamada et al., } \\
2008\end{array}$ \\
\hline Female & $\geq 60.0(72.2)$ & & & & 2,105 & & & \\
\hline Male & $\begin{array}{l}\geq 65.0 \text { (no average } \\
\text { age description } \\
\text { about male) }\end{array}$ & $\begin{array}{l}\text { NINDS, } \\
\text { Association } \\
\text { Internationale } \\
\text { pour la } \\
\text { Recherche et } \\
\text { I'Enseignement } \\
\text { en } \\
\text { Neuroscience's } \\
\text { criteria, CDR } \\
\text { scale, } \\
\text { DSM-III-R }\end{array}$ & $\begin{array}{l}\text { Education (number } \\
\text { of years of } \\
\text { schooling) }\end{array}$ & $\begin{array}{l}\text { Age, sex, education in } \\
\text { years, apolipoprotein } \\
\text { E4 allele, hypertension, } \\
\text { high cholesterol, } \\
\text { diabetes, Prevalence of } \\
\text { cardiovascular and } \\
\text { cerebrovascular } \\
\text { factors, obesity, stroke, } \\
\text { CABG, myocardial } \\
\text { infarction }\end{array}$ & 1,322 & $\begin{array}{l}\text { Vascular factors } \\
\text { increase risks for } \\
\text { AD and VaD } \\
\text { differentially by sex. }\end{array}$ & $\begin{array}{l}\text { Adjusted for all } \\
\text { covariates listed in } \\
\text { the medical risk } \\
\text { factors list }\end{array}$ & $\begin{array}{l}\text { Steinberg et al., } \\
2014\end{array}$ \\
\hline Female & $\geq 65.0(74.0)$ & & & & 1,801 & & & \\
\hline Male & $\begin{array}{l}\geq 65.0 \text { (no average } \\
\text { age description } \\
\text { about male) }\end{array}$ & $\begin{array}{l}\text { MMSE, } \\
\text { MRI-based } \\
\text { evidence of } \\
\text { lacunar state or } \\
\text { ischemic } \\
\text { WMLs, ADL, } \\
\text { IADL, HDRS, } \\
\text { Stroop T }\end{array}$ & Education (years) & $\begin{array}{l}\text { Sex, hypertension, } \\
\text { diabetes, } \\
\text { hypercholesterolemia, } \\
\text { coronary artery } \\
\text { disease, tobacco } \\
\text { smoking, atrial } \\
\text { fibrillation, neurologic } \\
\text { signs, family history, } \\
\text { history of depression. }\end{array}$ & 156 & $\begin{array}{l}\text { Moderate mocha } \\
\text { coffee consumption } \\
\text { was associated } \\
\text { with higher } \\
\text { cognition and } \\
\text { mood } \\
\text { status in } \\
\text { non-demented } \\
\text { elderly subjects } \\
\text { with VCl. No } \\
\text { description } \\
\text { regarding relation of } \\
\text { sex. }\end{array}$ & No description & Fisicaro et al., 2021 \\
\hline
\end{tabular}


TABLE 1 | Continued

\begin{tabular}{|c|c|c|c|c|c|c|c|c|}
\hline Sex & $\begin{array}{l}\text { Age in years } \\
\text { (Average age) }\end{array}$ & $\begin{array}{l}\text { Diagnostic } \\
\text { criteria }\end{array}$ & $\begin{array}{l}\text { Education and } \\
\text { marital status }\end{array}$ & $\begin{array}{l}\text { Medical risk } \\
\text { factors }\end{array}$ & Subjects & Key findings & $\begin{array}{l}\text { Adjusted } \\
\text { variables }\end{array}$ & References \\
\hline Female & $\begin{array}{l}\geq 65.0 \text { (no average } \\
\text { age description } \\
\text { about female) }\end{array}$ & & & & 144 & & & \\
\hline Male & $\begin{array}{l}\text { 16-102 (no } \\
\text { average age } \\
\text { description about } \\
\text { male and/or female) }\end{array}$ & $\begin{array}{l}\text { The } \\
\text { Cross-Cultural } \\
\text { Cognitive } \\
\text { Examination } \\
\text { and National } \\
\text { Institute of } \\
\text { Neurological } \\
\text { and } \\
\text { Communicative } \\
\text { Disorders and } \\
\text { Stroke and the } \\
\text { Alzheimer's } \\
\text { Disease and } \\
\text { Related } \\
\text { Disorders } \\
\text { Association } \\
\text { Alzheimer's } \\
\text { criteria }\end{array}$ & - & $\begin{array}{l}\text { Sex, type } 2 \text { diabetes, } \\
\text { lifestyle, cigarette } \\
\text { smoking, and obesity }\end{array}$ & $\begin{array}{c}\text { 2,310,330 } \\
\text { individuals, } \\
\text { and } \\
102,174 \\
\text { dementia } \\
\text { case } \\
\text { patients (no } \\
\text { separate } \\
\text { male and } \\
\text { female } \\
\text { number } \\
\text { description) }\end{array}$ & $\begin{array}{l}\text { Women with } \\
\text { diabetes had a } \\
19 \% \text { greater risk for } \\
\text { the development of } \\
\text { vascular dementia } \\
\text { than men. }\end{array}$ & $\begin{array}{l}\text { Age, race, systolic } \\
\text { blood pressure, } \\
\text { self-report } \\
\text { diabetes; total } \\
\text { cholesterol, } \\
\text { hypertension, } \\
\text { alcohol. }\end{array}$ & $\begin{array}{l}\text { Chatterjee et al., } \\
2016\end{array}$ \\
\hline \multicolumn{9}{|l|}{ Female } \\
\hline Male & & $\begin{array}{l}\text { STROBE, } \\
\text { ARIC, CARDIA, } \\
\text { CHS, FOS, } \\
\text { NOMAS. }\end{array}$ & $\begin{array}{l}\text { Education ( } \leq 8 \text { th } \\
\text { grade, grades } \\
\text { 9-11, completed } \\
\text { high school, some } \\
\text { college but no } \\
\text { degree, } \geq \text { College } \\
\text { graduate) }\end{array}$ & $\begin{array}{l}\text { Age, race, education, } \\
\text { alcoholic, cigarette } \\
\text { smoking, any physical } \\
\text { activity, BMI, waist } \\
\text { circumference, history } \\
\text { of arial fibrillation, LDL } \\
\text { cholesterol, } \\
\text { antihypertensive } \\
\text { medication, }\end{array}$ & 11775 & $\begin{array}{l}\text { The results of this } \\
\text { cohort study } \\
\text { suggest that } \\
\text { women may have } \\
\text { greater cognitive } \\
\text { reserve but faster } \\
\text { cognitive decline } \\
\text { than men, which } \\
\text { could contribute to } \\
\text { sex differences in } \\
\text { late-life dementia. }\end{array}$ & No description & Levine et al., 2021 \\
\hline Female & & & & & 14313 & & & \\
\hline
\end{tabular}


Aetiology Schedule; bADL's, Katz's Index for basic activities of daily living; IADL's, the Lawton and Brody scale for instrumental activities of Daily Living Scale; EURODEM, European Studies of Dementia; GMS, Geriatric Mental State Examination; CAMCOG, Cambridge Examination of Mental Disorders Cognitive Test; CASI, Cognitive Abilities

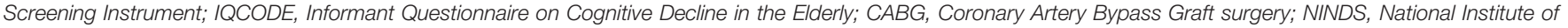

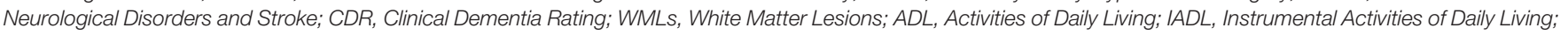

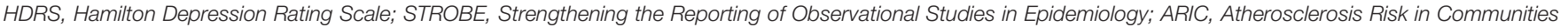

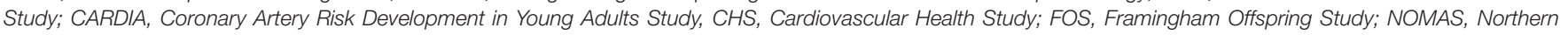
Manhattan Study.

(PD) (Kim et al., 2018). Therefore, studies are needed to investigate sex-specific differences, which can help understand the pathophysiology of dementia and identify potential therapeutic targets for both sexes. In response to variables that promote either positive or negative neuroplasticity, an individual's overall cognitive state might change over time. The physiological ability of the brain to establish and strengthen dendritic connections, cause good morphological changes, and boost cognitive reserve is referred to as positive neuroplasticity. Negative neuroplasticity refers to the same physiological ability of the brain to atrophy and weaken dendritic connections, produce detrimental morphological changes, and decrease cognitive reserve. Many factors promote positive or negative neuroplasticity including sex. Though women showing a greater risk of $\mathrm{AD}$ at later ages (Lin and Doraiswamy, 2014), it has been suggested that diagnosis of mild cognitive impairment (MCI) may be delayed in females, which may be responsible for the possible increased risk for MCI seen in males. Specifically, despite identical levels of neurodegeneration, females perform better in verbal memory than males (Sundermann et al., 2016a,b). This study shows that women have a cognitive reserve in this area, delaying the onset of abnormalities until higher levels of disease are present. Although the correlations are varied and multifaceted, there are sex differences in dementia. A study done in rats provides another example, showing that sex variations in neuroplasticity are the response of hippocampal neurogenesis to prolonged estradiol therapy (Barker and Galea, 2008).

With the prevalence of cardiovascular disease in recent years, the risk of $\mathrm{VaD}$ is also on the rise. Besides just simply having any form of cardiovascular disease, other factors can help contribute to developing $\mathrm{VaD}$ in some indirect ways. Sex can influence the occurrence of $\mathrm{VaD}$, and there are trends that $\mathrm{VaD}$ follows 
between the sexes. Some studies have shown a difference in how the prevalence of $\mathrm{VaD}$ is altered by a person's biological sex (Andersen et al., 1999; Podcasy and Epperson, 2016). The occurrence of dementia and the reasons for differences between the different sexes are complex. Like all dementia diagnoses, the symptoms can vary and are often caused by complex factors. There may not be a particular reason but a culmination of multiple factors at a personal level. For example, a woman experiencing menopause could also be experiencing symptoms of other health conditions that accumulate and lead to a higher risk of VaD (Robusto-Leitao and Ferreira, 2006; Yamada et al., 2008). Her risk is possibly higher than a male of similar age who only has hypertension. Additionally, another factor to consider besides age category risks is that females live $6+$ years longer than males on average, so their occurrence of $\mathrm{VaD}$ is higher based on longevity (Robusto-Leitao and Ferreira, 2006). These factors only consider physical factors, there may be many more, including educational level and socioeconomic status, etc. These additional factors can be attributed to a more social environment aspect of VaD. For example, the opportunities available for women vary in the sense of a generational gap. Females were placed into a social role of caretaking the household and had less physically demanding work roles than men (Hörder et al., 2018). Therefore, the risk of $\mathrm{VaD}$ could increase for women. Also, the occurrence of smoking has changed with time, it was less socially acceptable for women to smoke tobacco and other products but in recent years the number of female smokers has increased. These factors lead to a higher vascular risk and could be directly related to higher dementia cases in women in the long run (Zhong et al., 2015). Lastly, the sex differences noted in dementia are not really prominent until after the age of 80 , and that is only consistent in studies done in the United States (Podcasy and Epperson, 2016; Levine et al., 2021). Other studies in Europe show a sex difference in $\mathrm{VaD}$ early on, indicating that the occurrence of $\mathrm{VaD}$ can be influenced by external factors (Hasselgren et al., 2020). It is highly likely that each $\mathrm{VaD}$ diagnosis is unique and is a combination of both social and physical factors that affect an individual's neurobiology (Table 2).

\section{Pre-existing Health Conditions/Family History Risk Factors for VaD}

Perhaps one of the most common risk factors with any disease or condition is family history. A person's family history can indicate common trends and probabilities about a person's health, indicating what kind of lifestyle is best suited to everyone's needs. Indirectly a family history of cardiovascular disease can put a person, regardless of their sex, at a disadvantage for developing $\mathrm{VaD}$ because CVD is a hereditary risk factor that becomes a more significant risk factor for $\mathrm{VaD}$ (Treiber et al., 2008; Vijayan and Reddy, 2016). In terms of family history there are not many direct links of inherited conditions that can contribute directly to VaD. The only direct familial link to $\mathrm{VaD}$ occurs with gene variants and specific gene mutations (Lin et al., 2019). Additionally, the pre-existing health conditions that can contribute to $\mathrm{VaD}$ are smoking, obesity, hyperlipidemia, and old age (Tariq and Barber, 2018). Moreover, the factors mentioned are not specific to one sex but have been sorted by the sex in which the factor is more dominant (Podcasy and Epperson, 2016).

\section{Risk Factors for Males and Females}

The cardiovascular risk for $\mathrm{VaD}$ in women is less than that of men, but the prevalence varies (Steinberg et al., 2014). In the United States, men have a greater risk of having a heart attack and are twice more likely to have a heart attack than a women, yet the risk for CVD/heart disease is similar (Maas and Appelman, 2010). For smoking, worldwide, the trend has been consistent with men in developed countries smoking less than men in developing countries (Pampel, 2006). The use of tobacco products restricted to just the United States indicates that men smoke slightly more than women.

Researchers discovered a significant difference in age and education among the four groups of subjects based on their daily mocha coffee consumption. However, the General Regression Model revealed that the associations between coffee consumption and cognition and mood were independent of socio-demographic variables (Fisicaro et al., 2021). In terms of the sex-related effect, an earlier prospective study (Shinoda et al., 2015) of 455 participants (314 men) found that male drinkers had a lower incidence of small vessel disease than male nondrinkers and occasional drinkers, while female drinkers had a lower incidence of white matter lesions (WMLs) than female non-drinkers or occasional drinkers.

Obesity as a risk factor is prevalent in women, and overall globally, women tend to be more obese than men, but not in highly developed countries. The risk for smoking is also directly inverted for women. Women in developed countries, smoking more than currently developing countries. However, the gap within the United States of men and women smoking varies only by about 3\% (Mackay and Amos, 2003). Lastly, in terms of hyperlipidemia (Davidson et al., 2002) and anxiety (Santabárbara et al., 2020) condition, even though men have a higher risk for $\mathrm{VaD}$, and it is thought of as a man's disease, women are still at risk for high cholesterol, and the risk increases in women after menopause or early menopause. It is believed that younger women (or just generally those who have not reached menopause yet) are protected from more cardiovascular events than men due to the presence of high estrogen (El Khoudary et al., 2020).

\section{Overlapping Risk Factors}

As previously mentioned, there is no specific family history indicative of a high probability of developing $\mathrm{VaD}$, besides CVD. However, there is not a significant difference between males and females in this area. The percentage of lifestyle-influenced risk factors that contribute to $\mathrm{VaD}$ in the United States is mentioned in Table 3 (Whitmer et al., 2007; Gannon et al., 2019; Lewis et al., 2021). With these factors, other factors interrelated to family histories like gene variants and gene mutations can help contribute to VaD.

\section{Gene Variants as a Risk Factor for VaD}

Much work has been done on gene variants in $\mathrm{AD}$, and the effects of these genes in $\mathrm{VaD}$ have been rendered. The leading players in $\mathrm{VaD}$ include a mutation in the Notch Receptor 3 
TABLE 2 | General risk factors of VaD.

\begin{tabular}{|c|c|}
\hline \multicolumn{2}{|c|}{ Vascular dementia common risk factors } \\
\hline Genetics & Genetics can cause VaD depending on the presence of certain gene variants. This includes ApoE alleles and TDP43. \\
\hline Obesity & Obesity leads to VaD due to higher blood pressure. Over time this can cause ventricular enlargement and atherosclerosis. \\
\hline Hyperlipidemia & Hyperlipidemia blocks blood flow to the brain which overtime increases the chances of developing VaD. \\
\hline Diabetes & Type II diabetes is highly associated with VaD because of abnormal blood flow to the brain. Type I is associated but not as highly as Type II. \\
\hline Hypertension & Hypertension increases the risk of stroke which is a huge risk factor for VaD. \\
\hline Stroke & Stroke impedes blood flow to areas of the brain. The oxygen deprivation destroys the brain tissue. \\
\hline Atherosclerosis & Atherosclerosis prevents blood from reaching the brain fully. This deprives the tissue of the oxygen and nutrients. \\
\hline Atrial Fibrillation & Atrial fibrillation carries and increased risk of stroke which is directly linked to vascular dementia. \\
\hline Aging & Aging can increase the chance of $\mathrm{VaD}$ because there is a higher risk of atherosclerosis, heart attack and strokes. \\
\hline Smoking & Smoking increases the risk of stroke but additionally toxins in cigarette smoke cause oxidative stress and inflammation, both associated with \\
\hline
\end{tabular}

All these factors can overlap and when combined the risk of developing VaD increases.

(NOTCH3) gene, which is directly responsible for one form of VaD, and Apolipoprotein E (APOE) variants (Skoog et al., 1998; Thomas et al., 2000; Cho et al., 2021). NOTCH3 is directly linked to cerebral autosomal dominant arteriopathy with subcortical infarcts and leukoencephalopathy also known as CADASIL (Papakonstantinou et al., 2019). CADASIL is considered a very rare disease and has been recorded across all ethnic groups thus far (Kalaria et al., 2004). It is most often caused by a missense mutation but can alternatively be caused by null mutations or homozygous mutations. The symptoms of CADASIL include smaller cerebral vessels which in turn cause strokes, mood disturbances, and of course VaD (Dichgans, 2002). The other gene attributed as a risk factor for $\mathrm{VaD}$ is $\mathrm{APOE}$ and its variants (Skillbäck et al., 2018; Montagne et al., 2020). APOE has different variants denoted by e2 (APOE2), e3 (APOE3), and e4 (APOE4).

Astrocytes predominantly express APOE variants (APOE4) in the brain, cell types that are now recognized to play critical roles in largely lipid distribution, cerebrovascular function amyloid deposition, Tau phosphorylation, mitochondrial dysfunction (Fernandez et al., 2019), as depicted in Figure 3. Most of the research surrounding APOE has been centered around $\mathrm{AD}$, however, the same relationships established between APOE and $\mathrm{AD}$ apply to $\mathrm{VaD}$ but in a lesser magnitude (Alam et al., 2014). For example, APOE4 has been the most prominent contributor to $\mathrm{AD}$, and when two copies of the APOE4 allele are present the risk for $\mathrm{AD}$ increases 15 -fold. This increase is directly analogous to $\mathrm{VaD}$ because the same APOE $\mathrm{e} 4$ variant is the same variant that influences the risk for VaD. However, the effect is weaker and does not increase the risk as dramatically as 15-fold (Rohn, 2014).

\section{Risk Factors for Males and Females}

Males have a decreased risk of $\mathrm{VaD}$ in carrying an APOE4 variant even if the male is homozygous, the link between APOE

TABLE 3 | Percentage of lifestyle influenced risk factors that contribute to VaD.

\begin{tabular}{lcc}
\hline & Males & Females \\
\hline Obesity & $35 \%$ & $40.4 \%$ \\
Hyperlipidemia & $28.5 \%$ & $8.9 \%$ \\
Smoking & $16.7 \%$ & $13.6 \%$
\end{tabular}

and $\mathrm{AD} / \mathrm{VaD}$ is well established with females and not males (Rasmussen et al., 2018). This is such an important factor that even most studies involving tracing APOE to dementia are done with female mice (Adeosun et al., 2019). Most literature also supports that APOE2 and APOE3 are neutral factors in males developing VaD (Folin et al., 2004; Bell et al., 2012). In terms of the mutation for CADASIL, men have equal risk, but the symptoms of CADASIL affect men differently (Ruitenberg et al., 2001; Singhal et al., 2004). Men have more strokes on average than women at a younger age and retain cognitive ability better than women after a certain age (typically when comparing the sexes before menopause). APOE4 carries the highest risk for women developing dementia, especially for women who are homozygotes and carry two e4 alleles (Molero et al., 2001; Davidson et al., 2006). It is estimated that the risk increases 10fold for $\mathrm{VaD}$ and an earlier onset of dementia if a person is homozygous. APOE2 is the least common allele but provides a protective effect against dementia and cognitive decline in women (Volgman et al., 2019). CADASIL affects women mainly by increasing the occurrence of frequent migraines accompanied by vision impairment (Rufa et al., 2004; Guey et al., 2016). This is most prevalent until the age of menopause and then cognitive impairment becomes more evident. The occurrence of psychiatric symptoms and migraines increase after menopause, but women, however. have a decreased rate of strokes in comparison to men (Bushnell et al., 2014).

\section{Overlapping in Gene Variants}

Overall, both males and females have an equivalent risk of having CADASIL. The symptoms do vary, and that aspect is dictated by the age of the male or female. There also was no inconsistency between sex and the type of mutations that caused CADASIL (Mizuno et al., 2020). When it comes to APOE as a contributor to $\mathrm{VaD}$, however, there is a significant difference between males and females (Molero et al., 2001). Females have a higher risk than males when it comes to having variant APOE4 and females had a decreased risk when they carried APOE2. Males had a generally neutral experience when carrying alleles of APOE2 and APOE3. Lastly, APOE4 was not shown to be as much of an indicator in males for $\mathrm{VaD}$ as much as females (Molero et al., 2001; Li et al., 2017). 


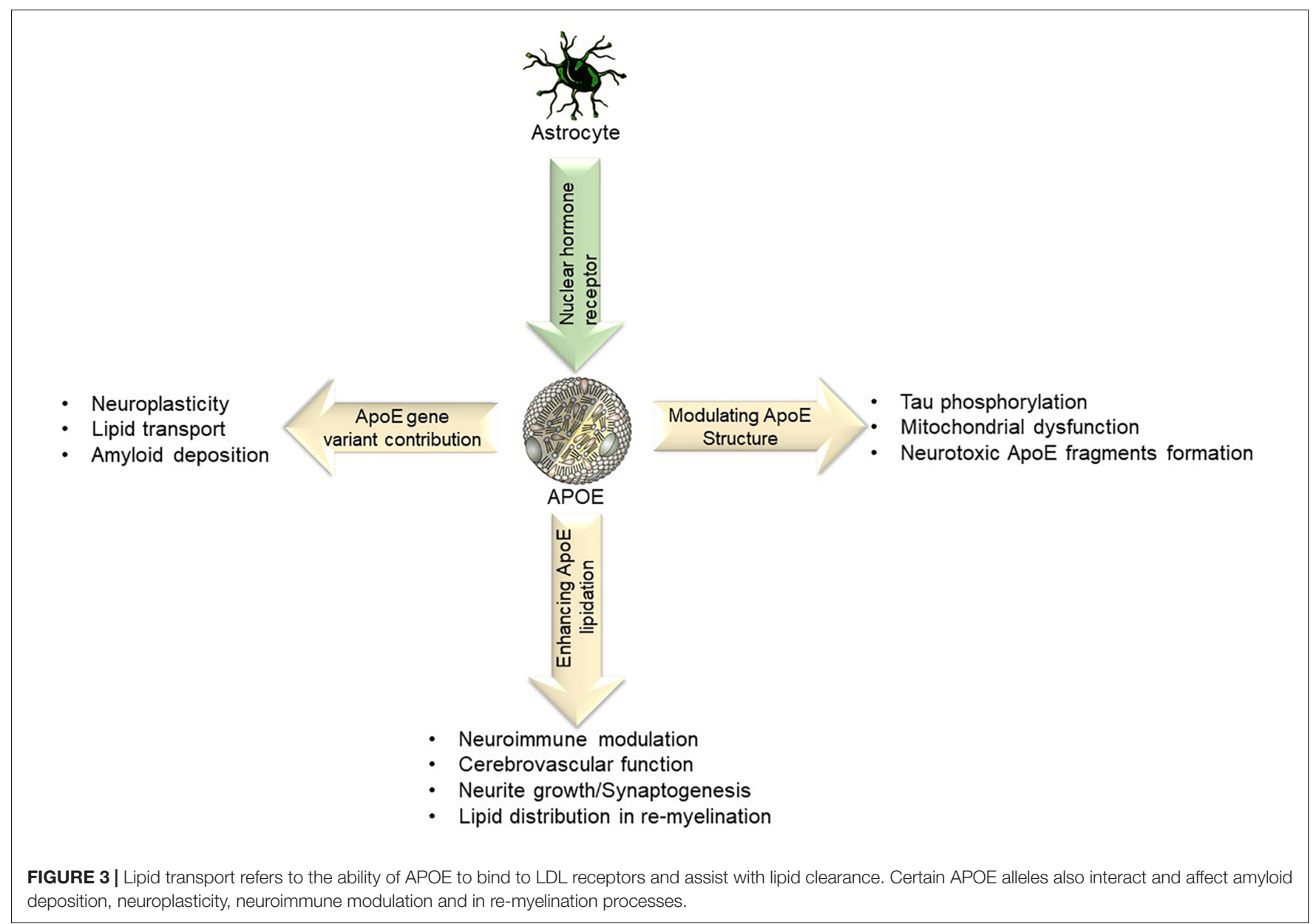

\section{Aging as a Risk Factor}

Aging is one of the leading and highest risk factors of $\mathrm{VaD}$ because of the association of adiponectin (Song et al., 2014). Adiponectin is a protein hormone secreted by adipose tissue (fat cells). In aging, adiponectin plasma levels decrease, leading to an increased risk of CVD and diabetes, considered a risk factor of VaD (Song et al., 2014; Chatterjee et al., 2016; Chen et al., 2019). Additionally, adiponectin plays a massive role in cognitive dysfunction by controlling the insulin signal transduction in the brain (Rizzo et al., 2020). An epidemiology study implies that there is an exponential increase in dementia after the age of 65 by double around every 5 years. However, for participants aged 90 and older, dementia doubles every 5 years for females but not males (Corrada et al., 2010).

Vascular dementia and multi-infarct dementia are most common in males but have a higher gravity of impact in females. The study concluded that stroke prevalence, whether ischemic or hemorrhagic, was $44 \%$ greater in males than in females worldwide. Also, males experience their first strokes at a younger age than females (68.6 vs. 72.9 years) (Persky et al., 2010; Girijala et al., 2017). Although males' first stroke experience might be at a younger age than females, females have a higher risk of lifetime stroke because of their longer life expectancy, which also increases the risk of stroke with age (Reeves et al., 2008).

\section{Hormone Fluctuations as a Risk Factor}

Studies have been done to investigate the controversy between correlating estrogen changes to cognitive impairment, which causes VaD (Ali et al., 2018). The reason for this occurrence is the sudden downfall of estrogen in women during menopause; this happens to be one of the significant risk factors and the root prevalence of $\mathrm{VaD}$ in postmenopausal females. Furthermore, a few studies concluded that estrogen deficiency in postmenopausal women is indeed one of the risk factors, causing cognitive deficit that can lead to $\mathrm{VaD}$ (Robusto-Leitao and Ferreira, 2006). The four-core genotype (FCG) model is used to separate the contributions of sex hormones and sex chromosome complement (Bushnell et al., 2018). The sex determining SRY gene is relocated from the $\mathrm{Y}$ chromosome to an autosome in this scenario, allowing XX males (XXM) and XY females (XYF) to be produced. Because the created XXM have a hormonal status like that of XY males (and vice versa for XYF and $\mathrm{XX}$ females), a comparison between the two provides for a better understanding of chromosome vs. hormone impacts. In addition, sex chromosomes have received little consideration in connection to the pathogenesis of dementia (Rocca et al., 2014). Women have two copies of chromosome $\mathrm{X}$, one from their mother and one from their father. The androgen receptor and many proteins involved in mitochondrial function, adipose tissue 
distribution, apoptosis, and sensitivity to hypoxia are among the approximately 1,600 genes (about 155 million base pairs) on the X-chromosome (Wise et al., 2013). In female cells, most of the genes expressed on one of the two X-chromosomes are inactivated to avoid a genetic overload (Brown et al., 1991). As a result, $\mathrm{X}$-chromosome inactivation patterns may provide a new viewpoint on the concept of laterality of brain activities in women vs. men.

\section{Male vs. Female Hormonal Risk/Benefits}

Females seem to be more susceptible overall to dementia than males. The association between sex hormones and $\mathrm{VaD}$ is still somewhat unknown in the scientific/medical field. While there is extended gratitude to consider sex as one of the factors of $\mathrm{VaD}$, there are various factors that might distinctively impact females, such as pregnancy and reproductive history.

A study was focused on a comparison between serum sex hormone levels among $\mathrm{VaD}$ patients (males and females) and normal (controls) individuals to bridging the gap between sex hormones level and cognitive and neuropsychiatric manifestations of VaD (Xing et al., 2013). The results of the study showed that the testosterone and sex hormone-binding globulin (SHBG) levels were lower in male $\mathrm{VaD}$ patients, and the estradiol levels were found to be higher in female $\mathrm{VaD}$ patients in comparison to the controls. The study concluded that there were no correlations between hormone levels and neuropsychiatric symptoms in male $\mathrm{VaD}$ patients, whereas total estradiol (TE2) and testosterone (TT) levels were positively correlated in female $\mathrm{VaD}$ patients. Estrogens influence the function and pathophysiology of cerebral circulation. Estrogen decreases cerebral vascular tone and increases cerebral blood flow by enhancing endothelial-derived nitric oxide and prostacyclin pathways (Krause et al., 2006). In addition, however, blood vessels produce inflammatory factors that could contribute to $\mathrm{VaD}$ pathology. One study suggests that estrogens and their receptors may regulate the neuroinflammatory response, and in females, circulating estrogens may play a protective, antiinflammatory role (Villa et al., 2016). Thus, estrogen preserves vascular function and neuroinflammatory response could be directly relevant to $\mathrm{VaD}$.

Another study on animal models suggests that young adult male mice had worse pathological and functional outcomes following cerebral ischemia than females, which is consistent with clinical studies suggesting that high-androgen levels enhance stroke risk in younger populations (Abi-Ghanem et al., 2020). These sex differences could be due to sex hormones or sex chromosomal complement.

\section{Hormone Therapy Risks/Benefits for VaD}

Hormone replacement therapy (HRT) can be used for a variety of reasons, even to deal with symptoms of the menopause. As previously mentioned, women have protection against forms of dementia due to their high estrogen levels. Once menopause is reached, however, those estrogen levels deplete. In these cases, women can have added protection against $\mathrm{VaD}$ despite their initial lower estrogen. A few studies finding a correlation have analyzed the relationship between HRT, AD and VaD specifically.
One study achieved that estradiol-based HRT was associated with a reduced risk of death both from $\mathrm{VaD}$ and $\mathrm{AD}$, but the risk reduction was larger and appeared sooner in $\mathrm{VaD}$ than $\mathrm{AD}$ (Mikkola et al., 2017). In a few studies, the use of estrogen postmenopause decreased the user's risk for dementia and improved cognitive decline (Yaffe et al., 1998). Another study suggested that the prior use of estrogen was more effective in combating dementia and cognitive decline as opposed to using HRT during post-menopause (Henderson, 2008). Most types of HRT increase the risk of breast, ovarian and, womb cancer (D'Alonzo et al., 2019). But the risk is higher for those using combined HRT, which uses both estrogen and progestogen. The risk of cancer due to HRT can also vary from person to person. Things such as what age you are when you first start taking HRT, other medicines you may be taking, and your general health can impact the risk. People who begin HRT before or soon after menopause may have a bigger risk than those who start HRT later (Beral et al., 2011). In one such study, HRT was analyzed in postmenopausal women and the results indicated that HRT contributed to vascular risk factors including stroke and could not sufficiently demonstrate benefits for postmenopausal women regarding dementia (Hogervorst et al., 2000). The results are clearly divided for the use of HRT, but the main conclusion most studies come to is that HRT can be beneficial if used within a proper time frame to protect postmenopausal women from dementia forms.

\section{Environmental Factors as a Risk Factor}

The physical risk factors of $\mathrm{VaD}$ are only one aspect of the cause. $\mathrm{VaD}$ can arise due to many factors but one class of factors that are often overlooked are the environmental factors which often can dictate some of the other more tangible, direct factors (Killin et al., 2016). Some environmental risk factors include air quality elements, toxic heavy metals, trace elements, known occupational hazards, electrical/magnetic fields, and a few others (Killin et al., 2016; Bellou et al., 2017; Wang et al., 2019). These different environmental factors have been shown to have strong effects in propagating dementia (Table 4).

The factors listed in the table are the highest environmental factors that have a link to $\mathrm{VaD}$, and they all are produced in different ways, some of which cannot be simply avoided. These factors can trickle down, and most likely do not directly affect the development of $\mathrm{VaD}$ but can exacerbate other existing risk factors. For example, the use of herbicides, pesticides, insecticides, and fertilizers are commonly used in farming practices all over the world, many of these are known endocrine disruptors that increased the risk of developing dementia (Kamel and Hoppin, 2004).

Other less obvious environmental factors can include weather patterns that govern a certain area as well as Vitamin D level deficiencies from lack of sunlight exposure (Sommer et al., 2017). The area in which a person lives can also influence the risk of $\mathrm{VaD}$. For example, one study done in China indicated that in areas with less particulate that the people in those areas had a reduced occurrence of cerebrovascular events (Cai et al., 2018). Reduced risk of cerebrovascular events decreases the risk of $\mathrm{VaD}$ because if harmful vascular events do not occur, there is no disruption 
TABLE 4 | Shows the various types of environmental factors and their uses.

\begin{tabular}{|c|c|c|}
\hline Environmental factor & Factor & How it is produced/or used \\
\hline \multirow[t]{2}{*}{ Air Quality } & Nitrous Oxides & $\begin{array}{l}\text { Combustion, especially in areas } \\
\text { of high motor vehicle use }\end{array}$ \\
\hline & Ozone & $\begin{array}{l}\text { UV Radiation reactions with } \\
\text { oxygen and sometimes } \\
\text { nitrogen oxides }\end{array}$ \\
\hline \multirow[t]{2}{*}{ Toxic Metals } & Arsenic & $\begin{array}{l}\text { Industrial use in mining and ore } \\
\text { smelting }\end{array}$ \\
\hline & Aluminum & Industrial mining and smelting \\
\hline \multirow[t]{2}{*}{ Trace Elements } & Silicon/Silica & $\begin{array}{l}\text { Industrial silicon and silica } \\
\text { working introduces fine } \\
\text { particles into the air }\end{array}$ \\
\hline & Selenium & mining/oil refining \\
\hline \multirow[t]{2}{*}{ Work Hazards } & $\begin{array}{l}\text { Pesticides/Herbicides/ } \\
\text { insecticides/fertilizers }\end{array}$ & $\begin{array}{l}\text { General farming and crop } \\
\text { production, can be endocrine } \\
\text { disrupting }\end{array}$ \\
\hline & $\begin{array}{l}\text { Solvents/degreasing } \\
\text { agents }\end{array}$ & $\begin{array}{l}\text { Industrial grade chemical for } \\
\text { various work trades }\end{array}$ \\
\hline
\end{tabular}

to brain tissue. Another study showed that with extremely low vitamin $\mathrm{D}$ levels patients were more likely to develop $\mathrm{VaD}$ and more likely to develop vascular events that perpetuated the occurrence of $\mathrm{VaD}$ (Chai et al., 2019). Another study indicated that warmer and wetter weather conditions provided for a better foundation for stroke patients to recover fully (Chen et al., 2013). This is important because stroke is one of the major contributors to $\mathrm{VaD}$ (Vijayan and Reddy, 2016). By making a full recovery from a stroke the risk of $\mathrm{VaD}$ is mitigated. Lastly, in one study air pollution and noise were linked to a progression of dementia in London, England (Carey et al., 2018). These results were more consistent with an $\mathrm{AD}$ diagnosis but there was a fair amount of VaD cases present as well.

\section{ACCESSIBLE TREATMENTS FOR VaD}

\section{Pharmaceutical Treatments}

Many drug categories have been used as a treatment for $\mathrm{VaD}$ patients. Some of these drug categories are vasodilators, calcium channel blockers, antiplatelet, etc. (Romàn, 2000; Chabriat and Bousser, 2006; Nimmrich and Eckert, 2013; Table 5). One of the most effective and standard treatment are cholinesterase inhibitors (Bullock, 2004). Cholinesterase inhibitors work by inhibiting acetylcholinesterase, which is accountable for clearing acetylcholine, a neurotransmitter responsible for muscle contractions, blood vessel dilation, and regulating heart rate. With the cholinesterase inhibited, the acetylcholine concentrations rise and lead to better communication between the nerve cells in the brain. An artificial increase in acetylcholine levels by physostigmine, an acetylcholinesterase inhibitor that increases the extracellular acetylcholine levels, impairs memory consolidation and rescue in rodent and human subjects (Haam and Yakel, 2017). Vasodilation drugs work mainly in preventing constriction of the blood vessels anywhere in the body and allowing greater blood flow. However, calcium channel blockers prevent calcium from entering the cells in the heart, vascular smooth muscle, and pancreas by lowering the blood pressure. Aspirin is a popular antiplatelet drug that works by blocking the movement of the cyclooxygenase chemical (COX) via the prostaglandin synthesis pathway (PGH2) (Warner et al., 2011; Ornelas et al., 2017).

The drugs that are mentioned in the table above are only the pharmaceutical treatments for VaD (Olivares et al., 2012; $\mathrm{Wu}$ et al., 2015). There have been a few studies indicating alternative treatments that have had success. The alternative and homeopathic treatments mostly treat the symptoms of the $\mathrm{VaD}$ but occasionally can treat the vascular underlying conditions (McCarney et al., 2003). A study done in 2018 concluded that acupuncture could in fact help to treat $\mathrm{VaD}$ and it generally worked by boosting the metabolism of glucose and oxygen, contributing to anti-oxidative stress reactions, and acted as an anti-apoptotic agent (Zhu et al., 2018). In another study, aromatherapy essential oils (rotated lemon, rosemary, lavender, and orange oils) were given to dementia patients topically throughout the day for a period of 28 days (Jimbo et al., 2009). After 28 days the aromatherapy was shown to have improved the patient's personal orientation and cognition. This improvement in the patients could be applied specifically to $\mathrm{VaD}$ and the treatment proved to be an efficacious non-pharmacological treatment. Music therapy was analyzed for its effect on dementia patients indicated that having at least 5 music therapy sessions a day reduced depression and generally improved the quality of life of dementia patients (van der Steen et al., 2018). The effects of music therapy on actual cognitive function were unknown, however. Lastly, art therapy was another means of homeopathic therapy, functioned similarly to music therapy in that it improved the patient's quality of life (Deshmukh et al., 2018). The actual cognitive function could not be measured but the therapy improved neuropsychiatric symptoms of dementia patients. While homeopathic remedies are a reasonable alternative, they tend to focus on the symptoms rather than the triggers. The causes of risk factors might be discussed in order to completely eliminate the risk of $\mathrm{VaD}$. Thus far, there is no drug available related to sex/gender and therefore, the development of pharmaceutical treatment for $\mathrm{VaD}$ has become an essential but unmet need.

\section{Elimination of Risk Factors}

Eliminating a risk factor should zero in on a reduction of the major causes of $\mathrm{VaD}$ such as stroke, and $\mathrm{CVD}$, with consideration regarding controlling of the other risk factors. One of the biggest risk factors for $\mathrm{VaD}$ is arterial hypertension (Paglieri et al., 2004). Arterial hypertension is the main cause of $50 \%$ of strokes regardless of the pathogenic mechanism involved. Also, lower blood pressure decreases the risk of $\mathrm{VaD}$ by $55 \%$ (Sierra, 2020). Indeed, the primary prevention focus is to decrease the prevalence of $\mathrm{VaD}$ by early and optimum treatment for stroke and CVD by targeting high-risk groups such as the elderly, hypertensive patients, diabetes patients, smokers, past transient ischemic attack or stroke survivors, hypercholesterolemia patients, and atrial fibrillation patients (Vijayan and Reddy, 2016). 
TABLE 5 | Pharmacological treatment for $\mathrm{VaD}$ and their effects.

\begin{tabular}{|c|c|c|}
\hline Drug classes & Drugs & Effects \\
\hline Cholinesterase inhibitors & Donepezil, Galantamine, Rivastigmine & $\begin{array}{l}\text { Safe and effective in reducing the progression of } \\
\mathrm{VaD} \text { in addressing the behavioral problems. }\end{array}$ \\
\hline Vasodilators & $\begin{array}{l}\text { Niacin (nicotinic acid), Cyclandelate, Papaverine, } \\
\text { Isoxsuprine, Cinnarizine, Buflomedil, Naftidrofuryl, } \\
\text { Ergoloid mesylates, Acetazolamide }\end{array}$ & $\begin{array}{l}\text { Have shown to be less effective in treating VaD } \\
\text { compared to cortical dementias like Alzheimer's. }\end{array}$ \\
\hline Calcium channel blockers & Nimodipine & $\begin{array}{l}\text { Moderately effective for short term in treating } \\
\text { cerebrovascular disease and other types of } \\
\text { dementia. }\end{array}$ \\
\hline N-methyl-D-aspartate (NMDA) antagonists & Nicardipine & Improvement of cognitive deterioration \\
\hline NMDA antagonists & Memantine & $\begin{array}{l}\text { Improve cognition consistently across different } \\
\text { cognitive scales, with at least no deterioration in } \\
\text { global functioning and behavior. }\end{array}$ \\
\hline Nootropic agents & $\begin{array}{l}\text { Piracetam, Nicergoline, Oxiracetam } \\
\text { Citicoline, Pentoxifylline }\end{array}$ & $\begin{array}{l}\text { have beneficial effects for patients with dementia in } \\
\text { prolonging their survival. }\end{array}$ \\
\hline Antiplatelet agents & Aspirin, Triflusal, Ginkgo biloba & Reduce/prevent the occurrence of stroke. \\
\hline
\end{tabular}

The primary prevention aims to minimize dementia in the population by advising lifestyle changes such as the control of diabetes and hypertension (Eggink et al., 2019). The secondary prevention methods aim to mark stroke management and the prevention of recurrent stroke (Lip and Kalra, 2010). This has shown a $50 \%$ decrease in the risk of dementia in those with previous stroke experiences and a 16\% decrease in those without stroke experiences in patients without cognitive impairment (Lo Coco et al., 2016).

The specific ways that dementia patients or dementia patient caregivers are prescribed to help reduce symptoms include lifestyle changes. These lifestyle changes are aimed at improving the vascular health of the body to reduce any kind of negative events like stroke or heart attack. The methods include diet changes, incorporating exercise either vigorous or more passive, cognitive therapy, and management of vascular issues like hypertension through medication. A research study published in 2016 demonstrated the effectiveness of integrating exercise into a stroke rehabilitation environment (Winstein et al., 2016). Stroke patients who included moderate aerobic activity and environmental enrichment in their treatment plans had higher recovery rates and, in some cases, spontaneous recovery. Another research published in 2018 found that incorporating passive exercise into a dementia patient's everyday routine resulted in substantial improvements in quality of life and activities of daily living (Zucchella et al., 2018). Most of the patients in this study improved their cognitive and physical functioning. A study done in Finland called the FINGER trial was aimed at improving the outcomes in $\mathrm{VaD}$ patients through a total reset of the patient's lifestyle (Kivipelto et al., 2020). With regular medical advice, intervention (diet, exercise, vascular risk management, lifestyle guidance, intellectual training, social activities, cognitive training, prevent head injury, stop smoking, reduce air pollution), and multi-domain intervention, cognitive function was partially restored. Another method to reduce symptoms of $\mathrm{VaD}$ includes cognitive therapy was done in 2019 aimed to test individuals with mild to moderate $\mathrm{VaD}$ and to view if there were any cognitive changes (Peng, 2019). There was no net improvement in the cognition of the dementia patients, but of those that had caregivers, the moods of the caregivers were improved and in turn led to a better mood and outlook for the dementia patients. As for medication, several drugs have been prescribed to treat $\mathrm{VaD}$ after the risk factors have been addressed. Since zinc deficiencies play a critical role in neurodegenerative diseases, a study published in 2018 found that carnosine and zinc, which are commonly used as a supplement to treat gastric ulcers, may be used as a future remedy for VaD (Kawahara et al., 2018). Lastly, in a study done in 2016, amlodipine, a common hypertension treatment was given to $\mathrm{VaD}$ patients (Fares et al., 2016). There was a slight improvement in the symptoms of $\mathrm{VaD}$ patients. Even though there is little research on non-traditional therapies, there is still a lot of importance in looking into the options with $\mathrm{VaD}$ since there is no standardized care. $\mathrm{VaD}$ is very challenging to treat, and this is partially due to a lack of understanding of the full pathophysiology.

\section{CONCLUSION}

With the rise of $\mathrm{VaD}$ cases across the globe, it is easy to see why researchers have taken an interest in its risk factors. An overlooked factor is often sex and gender. In this review, we explored the impact of sex/gender differences on $\mathrm{VaD}$, including how they affect these risk factors: preexisting health conditions and family history, gene variants, aging, hormone fluctuations, and environmental risk factors. Improvements in the following areas may help to reduce the prevalence of VaD: (1) stroke prevention in hypertensive patients, (2) appropriate treatment to prevent or slow atherosclerosis progression, (3) a better understanding of the relationship between menopause and hypertension control, and (4) efforts to reduce neurological complications associated with cardiac procedures, (5) avoiding poorly timed hormone replacement therapy (6) evading potentially dangerous drugs that impair memory and cognition, and (6) developing therapy targets based on a better understanding of the molecular function of 
the apolipoprotein E4 genotype in dementia. These all play a significant role in developing $\mathrm{VaD}$ and additionally should be monitored to reduce the risk. When it comes to sex and gender there is not a fine line between how $\mathrm{VaD}$ presents itself. $\mathrm{VaD}$ is a multidimensional illness with many different moving pieces, and every case of $\mathrm{VaD}$ has its risk factors that can be attributed to a plethora of lifestyle factors and chance. Future research should be focused on treating $\mathrm{VaD}$ by assessing the occurrence of risk factors in sex and a variety of other lifestyle indications to create a more tailored treatment plan. If enough research is done, a strong connection between sex and $\mathrm{VaD}$ could be discovered, which may aid in improving current therapies and developing unique sex-based treatment plans. Additionally, more research should also be conducted on how socioeconomic factors impact a patient's physiology and how that impacts their ability to develop VaD. This could be important due to how social constructs can dictate health based on sex. For example, females up until recently had a more social role of refraining from smoking to maintain a feminine image. In addition, more research should be planned on possible gene therapies and how the occurrence of $\mathrm{VaD}$ affects

\section{REFERENCES}

Abi-Ghanem, C., Robison, L. S., and Zuloaga, K. L. (2020). Androgens' effects on cerebrovascular function in health and disease. Biol. Sex Differ. 11:35.

Adeosun, S. O., Hou, X., Shi, L., Stockmeier, C. A., Zheng, B., Raffai, R. L., et al. (2019). Female mice with apolipoprotein E4 domain interaction demonstrated impairments in spatial learning and memory performance and disruption of hippocampal cyto-architecture. Neurobiol. Learn. Mem. 161, 106-114. doi: 10.1016/j.nlm.2019.03.012

Alam, R., Tripathi, M., Mansoori, N., Parveen, S., Luthra, K., Lakshmy, R., et al. (2014). Synergistic epistasis of paraoxonase 1 (rs662 and rs85460) and apolipoprotein E4 genes in pathogenesis of Alzheimer's disease and vascular dementia. Am. J. Alzheimers Dis. Other Demen. 29, 769-776. doi: 10.1177/ 1533317514539541

Ali, S. A., Begum, T., and Reza, F. (2018). Hormonal influences on cognitive function. Malays. J. Med. Sci. 25, 31-41.

Al-Qazzaz, N. K., Ali, S. H., Ahmad, S. A., Islam, S., and Mohamad, K. (2014). Cognitive impairment and memory dysfunction after a stroke diagnosis: a poststroke memory assessment. Neuropsychiatr. Dis. Treat. 10, 1677-1691. doi: 10.2147/ndt.s67184

Andersen, K., Launer, L. J., Dewey, M. E., Letenneur, L., Ott, A., Copeland, J. R., et al. (1999). Gender differences in the incidence of AD and vascular dementia: the EURODEM Studies. EURODEM incidence research group. Neurology 53, 1992-1997. doi: 10.1212/wnl.53.9.1992

Arrigo, A., Casale, R., Buonocore, M., and Ciano, C. (1990). Effects of acetyl-Lcarnitine on reaction times in patients with cerebrovascular insufficiency. Int. J. Clin. Pharmacol. Res. 10, 133-137.

Barker, J. M., and Galea, L. A. (2008). Repeated estradiol administration alters different aspects of neurogenesis and cell death in the hippocampus of female, but not male, rats. Neuroscience 152, 888-902. doi: 10.1016/j.neuroscience. 2007.10.071

Baskys, A., and Hou, A. C. (2007). Vascular dementia: pharmacological treatment approaches and perspectives. Clin. Interv. Aging 2, 327-335.

Bell, R. D., Winkler, E. A., Singh, I., Sagare, A. P., Deane, R., Wu, Z., et al. (2012). Apolipoprotein E controls cerebrovascular integrity via cyclophilin A. Nature 485, 512-516. doi: 10.1038/nature 11087

Bellou, V., Belbasis, L., Tzoulaki, I., Middleton, L. T., Ioannidis, J. P. A., and Evangelou, E. (2017). Systematic evaluation of the associations between environmental risk factors and dementia: an umbrella review of systematic reviews and meta-analyses. Alzheimers Dement. 13, 406-418. doi: 10.1016/j. jalz.2016.07.152 the LGBTQ+ community and changes their physiology. This would be particularly salient in studying the occurrence of all types of dementia and $\mathrm{VaD}$ in the transgender population and for individuals that use hormone replacement therapies. Lastly, future trials must examine sex-specific differences to improve our understanding of how CVD affects cognitive impairment in women and men.

\section{AUTHOR CONTRIBUTIONS}

FA, AP, and YZ drafted the manuscript and figures. ZZ and DZ proofread and revised the manuscript. DZ gave the final proof for this submission. All authors contributed to the article and approved the submitted version.

\section{FUNDING}

This work was supported by National Institutes of Health (Grant No. R01AG064798).

Benisty, S., Hernandez, K., Viswanathan, A., Reyes, S., Kurtz, A., O’Sullivan, M., et al. (2008). Diagnostic criteria of vascular dementia in CADASIL. Stroke 39, 838-844. doi: 10.1161/strokeaha.107.490672

Beral, V., Reeves, G., Bull, D., and Green, J. (2011). Breast cancer risk in relation to the interval between menopause and starting hormone therapy. J. Natl. Cancer Inst. 103, 296-305. doi: 10.1093/jnci/djq527

Brown, C. J., Ballabio, A., Rupert, J. L., Lafreniere, R. G., Grompe, M., Tonlorenzi, R., et al. (1991). A gene from the region of the human X inactivation centre is expressed exclusively from the inactive X chromosome. Nature 349, 38-44. doi: $10.1038 / 349038 \mathrm{a} 0$

Bullock, R. (2004). Cholinesterase inhibitors and vascular dementia: another string to their bow? CNS drugs 18, 79-92. doi: 10.2165/00023210-200418020-00002

Bushnell, C. D., Chaturvedi, S., Gage, K. R., Herson, P. S., Hurn, P. D., Jiménez, M. C., et al. (2018). Sex differences in stroke: challenges and opportunities. . Cereb. Blood Flow Metab. 38, 2179-2191.

Bushnell, C., McCullough, L. D., Awad, I. A., Chireau, M. V., Fedder, W. N., Furie, K. L., et al. (2014). Guidelines for the prevention of stroke in women: a statement for healthcare professionals from the American Heart Association/American Stroke Association. Stroke 45, 1545-1588.

Cai, J., Yu, S., Pei, Y., Peng, C., Liao, Y., Liu, N., et al. (2018). Association between airborne fine particulate matter and Residents' cardiovascular diseases, ischemic heart disease and cerebral vascular disease mortality in areas with lighter air pollution in China. Int. J. Environ. Res. Public Health 15:1918. doi: 10.3390/ ijerph15091918

Carey, I. M., Anderson, H. R., Atkinson, R. W., Beevers, S. D., Cook, D. G., Strachan, D. P., et al. (2018). Are noise and air pollution related to the incidence of dementia? A cohort study in London, England. BMJ open 8, e022404. doi: 10.1136/bmjopen-2018-022404

Caruso, P., Signori, R., and Moretti, R. (2019). Small vessel disease to subcortical dementia: a dynamic model, which interfaces aging, cholinergic dysregulation and the neurovascular unit. Vasc. Health Risk Manag. 15, 259-281. doi: 10.2147/ vhrm.s190470

Chabriat, H., and Bousser, M. G. (2006). Vascular dementia: potential of antiplatelet agents in prevention. Eur. Neurol. 55, 61-69. doi: 10.1159/000091981

Chai, B., Gao, F., Wu, R., Dong, T., Gu, C., Lin, Q., et al. (2019). Vitamin D deficiency as a risk factor for dementia and Alzheimer's disease: an updated meta-analysis. BMC Neurol. 19:284. doi: 10.1186/s12883-019-1500-6

Chatterjee, S., Peters, S. A., Woodward, M., Mejia Arango, S., Batty, G. D., Beckett, N., et al. (2016). Type 2 diabetes as a risk factor for dementia in women compared with men: a pooled analysis of 2.3 million people comprising more than 100,000 cases of dementia. Diabetes Care 39, 300-307. 
Chen, R., Shu, Y., and Zeng, Y. (2019). Links between adiponectin and dementia: from risk factors to pathophysiology. Front. Aging Neurosci. 11:356. doi: 10. 3389/fnagi.2019.00356

Chen, R., Wang, C., Meng, X., Chen, H., Thach, T. Q., Wong, C. M., et al. (2013). Both low and high temperature may increase the risk of stroke mortality. Neurology 81, 1064-1070. doi: 10.1212/wnl.0b013e3182a4a43c

Cho, B. P. H., Nannoni, S., Harshfield, E. L., Tozer, D., Gräf, S., Bell, S., et al. (2021). NOTCH3 variants are more common than expected in the general population and associated with stroke and vascular dementia: an analysis of 200000 participants. J. Neurol. Neurosurg. Psychiatry 92, 694-701. doi: 10.1136/ jnnp-2020-325838

Choi, H. I., Ryu, C. W., Kim, S., Rhee, H. Y., and Jahng, G. H. (2020). Changes in microvascular morphology in subcortical vascular dementia: a study of vessel size magnetic resonance imaging. Front. Neurol. 11:545450. doi: 10.3389/fneur. 2020.545450

Corrada, M. M., Brookmeyer, R., Paganini-Hill, A., Berlau, D., and Kawas, C. H. (2010). Dementia incidence continues to increase with age in the oldest old: the 90+ study. Ann. Neurol. 67, 114-121. doi: 10.1002/ana.21915

D'Alonzo, M., Bounous, V. E., Villa, M., and Biglia, N. (2019). Current evidence of the oncological benefit-risk profile of hormone replacement therapy. Medicina (Kaunas, Lithuania) 55, 573. doi: 10.3390/medicina55090573

Davidson, M. H., Maki, K. C., Karp, S. K., and Ingram, K. A. (2002). Management of hypercholesterolaemia in postmenopausal women. Drugs Aging 19, 169-178. doi: 10.2165/00002512-200219030-00002

Davidson, Y., Gibbons, L., Purandare, N., Byrne, J., Hardicre, J., Wren, J., et al. (2006). Apolipoprotein E epsilon4 allele frequency in vascular dementia. Dement. Geriatr. Cogn. Dis. 22, 15-19.

Debette, S., and Markus, H. S. (2010). The clinical importance of white matter hyperintensities on brain magnetic resonance imaging: systematic review and meta-analysis. BMJ (Clin. Res. ed.) 341:c3666. doi: 10.1136/bmj.c3666

Deshmukh, S. R., Holmes, J., and Cardno, A. (2018). Art therapy for people with dementia. Cochrane database Syst. Rev. 9:Cd011073.

Dichgans, M. (2002). CADASIL: a monogenic condition causing stroke and subcortical vascular dementia. Cerebrovasc. Dis. (Basel, Switzerland) 13(Suppl. 2), 37-41. doi: 10.1159/000049148

Dichgans, M., and Leys, D. (2017). Vascular cognitive impairment. Circ. Res. 120, 573-591.

Eggink, E., Moll van Charante, E. P., van Gool, W. A., and Richard, E. (2019). A population perspective on prevention of dementia. J. Clin. Med. 8, 834 . doi: $10.3390 / \mathrm{jcm} 8060834$

El Khoudary, S. R., Aggarwal, B., Beckie, T. M., Hodis, H. N., Johnson, A. E., Langer, R. D., et al. (2020). Menopause transition and cardiovascular disease risk: implications for timing of early prevention: a scientific statement from the American Heart Association. Circulation 142, e506-e532.

Engelhardt, E. (2017). Apoplexy, cerebrovascular disease, and stroke: historical evolution of terms and definitions. Dement. Neuropsychol. 11, 449-453. doi: 10.1590/1980-57642016dn11-040016

Fares, H., DiNicolantonio, J. J., O’Keefe, J. H., and Lavie, C. J. (2016). Amlodipine in hypertension: a first-line agent with efficacy for improving blood pressure and patient outcomes. Open Heart 3:e000473. doi: 10.1136/openhrt-2016-000473

Fernandez, C. G., Hamby, M. E., McReynolds, M. L., and Ray, W. J. (2019). The role of APOE4 in disrupting the homeostatic functions of astrocytes and microglia in aging and Alzheimer's disease. Front. Aging Neurosci. 11:14. doi: 10.3389/fnagi.2019.00014

Fisicaro, F., Lanza, G., Pennisi, M., Vagli, C., Cantone, M., Pennisi, G., et al. (2021). Moderate mocha coffee consumption is associated with higher cognitive and mood status in a non-demented elderly population with subcortical ischemic vascular disease. Nutrients 13:536. doi: 10.3390/nu13020536

Folin, M., Baiguera, S., Conconi, M. T., Di Liddo, R., De Carlo, E., Parnigotto, P. P., et al. (2004). Apolipoprotein E as vascular risk factor in neurodegenerative dementia. Int. J. Mol. Med. 14, 609-613.

Gannon, O. J., Robison, L. S., Custozzo, A. J., and Zuloaga, K. L. (2019). Sex differences in risk factors for vascular contributions to cognitive impairment \& dementia. Neurochemistry international 127, 38-55. doi: 10.1016/j.neuint.2018. 11.014

Girijala, R. L., Sohrabji, F., and Bush, R. L. (2017). Sex differences in stroke: review of current knowledge and evidence. Vasc. Med. (Lond. Engl.) 22, 135-145. doi: $10.1177 / 1358863 \times 16668263$
Glader, E. L., Stegmayr, B., Norrving, B., Terént, A., Hulter-Asberg, K., Wester, P. O., et al. (2003). Sex differences in management and outcome after stroke: a Swedish national perspective. Stroke 34, 1970-1975. doi: 10.1161/01.str. 0000083534.81284.c5

Guey, S., Mawet, J., Hervé, D., Duering, M., Godin, O., Jouvent, E., et al. (2016). Prevalence and characteristics of migraine in CADASIL. Cephalalgia 36, 10381047. doi: 10.1177/0333102415620909

Gunda, B., Hervé, D., Godin, O., Bruno, M., Reyes, S., Alili, N., et al. (2012). Effects of gender on the phenotype of CADASIL. Stroke 43, 137-141. doi: 10.1161/strokeaha.111.631028

Haam, J., and Yakel, J. L. (2017). Cholinergic modulation of the hippocampal region and memory function. J. neurochem. 142 Suppl 2(Suppl 2), 111-121. doi: $10.1111 /$ jnc. 14052

Hachinski, V. C., Lassen, N. A., and Marshall, J. (1974). Multi-infarct dementia. A cause of mental deterioration in the elderly. Lancet (Lond. Engl.) 2, 207-210. doi: 10.1016/s0140-6736(74)91496-2

Hachinski, V., Einhäupl, K., Ganten, D., Alladi, S., Brayne, C., Stephan, B. C. M., et al. (2019). Preventing dementia by preventing stroke: the Berlin Manifesto. Alzheimers Dement. 15, 961-984. doi: 10.1016/j.jalz.2019.06.001

Hanyu, H. (2012). [Diagnosis and treatment of mixed dementia]. Brain Nerve 64, 1047-1055.

Hasselgren, C., Ekbrand, H., Halleröd, B., Mellqvist Fässberg, M., Zettergren, A., Johansson, L., et al. (2020). Sex differences in dementia: on the potentially mediating effects of educational attainment and experiences of psychological distress. BMC Psychiatry 20:434. doi: 10.1186/s12888-020-02 820-9

Henderson, V. W. (2008). Cognitive changes after menopause: influence of estrogen. Clin. Obstet. Gynecol. 51, 618-626. doi: 10.1097/grf. 0b013e318180ba10

Hogervorst, E., Williams, J., Budge, M., Riedel, W., and Jolles, J. (2000). The nature of the effect of female gonadal hormone replacement therapy on cognitive function in post-menopausal women: a meta-analysis. Neuroscience 101, 485512. doi: 10.1016/s0306-4522(00)00410-3

Hörder, H., Johansson, L., Guo, X., Grimby, G., Kern, S., Östling, S., et al. (2018). Midlife cardiovascular fitness and dementia: a 44-year longitudinal population study in women. Neurology 90, e1298-e1305.

Huang, L. K., Chao, S. P., and Hu, C. J. (2020). Clinical trials of new drugs for Alzheimer disease. J. Biomed. Sci. 27:18.

Iulita, M. F., and Girouard, H. (2017). Treating hypertension to prevent cognitive decline and dementia: re-opening the debate. Adv. Exp. Med. Biol. 956, 447-473. doi: 10.1007/5584_2016_98

Jellinger, K. A. (2004). Pathology and pathophysiology of vascular cognitive impairment. A critical update. Panminerva Med. 46, 217-226.

Jian, W. X., Zhang, Z., Zhan, J. H., Chu, S. F., Peng, Y., Zhao, M., et al. (2020). Donepezil attenuates vascular dementia in rats through increasing BDNF induced by reducing HDAC6 nuclear translocation. Acta Pharmacol. Sin. 41, 588-598. doi: 10.1038/s41401-019-0334-5

Jimbo, D., Kimura, Y., Taniguchi, M., Inoue, M., and Urakami, K. (2009). Effect of aromatherapy on patients with Alzheimer's disease. Psychogeriatrics 9, 173-179.

Kalaria, R. N. (2016). Neuropathological diagnosis of vascular cognitive impairment and vascular dementia with implications for Alzheimer's disease. Acta Neuropathol. 131, 659-685. doi: 10.1007/s00401-016-1571-z

Kalaria, R. N., Akinyemi, R., and Ihara, M. (2016). Stroke injury, cognitive impairment and vascular dementia. Biochim. Biophys. Acta 1862, 915-925.

Kalaria, R. N., and Erkinjuntti, T. (2006). Small vessel disease and subcortical vascular dementia. J. clin. neurol. (Seoul, Korea) 2, 1-11. doi: 10.3988/jcn.2006. 2.1.1

Kalaria, R. N., Viitanen, M., Kalimo, H., Dichgans, M., and Tabira, T. (2004). The pathogenesis of CADASIL: an update. J. Neurol. Sci. 226, 35-39. doi: 10.1016/j.jns.2004.09.008

Kamel, F., and Hoppin, J. A. (2004). Association of pesticide exposure with neurologic dysfunction and disease. Environ. Health Perspect. 112, 950-958. doi: 10.1289/ehp.7135

Kandiah, N., Pai, M. C., Senanarong, V., Looi, I., Ampil, E., Park, K. W., et al. (2017). Rivastigmine: the advantages of dual inhibition of acetylcholinesterase and butyrylcholinesterase and its role in subcortical vascular dementia and Parkinson's disease dementia. Clin. Interven. Aging 12, 697-707. doi: 10.2147/ cia.s129145 
Kawahara, M., Tanaka, K. I., and Kato-Negishi, M. (2018). Zinc, carnosine, and neurodegenerative diseases. Nutrients 10:147. doi: 10.3390/nu10020147

Kennelly, S. P., Lawlor, B. A., and Kenny, R. A. (2009). Blood pressure and dementia - a comprehensive review. Ther. Adv. Neurol. Dis. 2, 241-260. doi: $10.1177 / 1756285609103483$

Killin, L. O., Starr, J. M., Shiue, I. J., and Russ, T. C. (2016). Environmental risk factors for dementia: a systematic review. BMC Geriatr. 16:175. doi: 10.1186/ s12877-016-0342-y

Kim, M. Y., Kim, K., Hong, C. H., Lee, S. Y., and Jung, Y. S. (2018). Sex differences in cardiovascular risk factors for dementia. Biomol. Ther. 26, 521-532. doi: 10.4062/biomolther.2018.159

Kivipelto, M., Mangialasche, F., Snyder, H. M., Allegri, R., Andrieu, S., Arai, H., et al. (2020). World-Wide FINGERS network: a global approach to risk reduction and prevention of dementia. Alzheimers Dement. 16, 1078-1094.

Korczyn, A. D., Vakhapova, V., and Grinberg, L. T. (2012). Vascular dementia. J. Neurol. Sci. 322, 2-10.

Krause, D. N., Duckles, S. P., and Pelligrino, D. A. (2006). Influence of sex steroid hormones on cerebrovascular function. J. Appl. Physiol. (Bethesda, Md 101, 1252-1261. doi: 10.1152/japplphysiol.01095.2005

Lechner, H., and Bertha, G. (1991). Multi-infarct dementia. J. Neural Transm. Suppl. 33, 49-52.

Lee, A. Y. (2011). Vascular dementia. Chonnam Med. J. 47, 66-71.

Levine, D. A., Gross, A. L., Briceño, E. M., Tilton, N., Giordani, B. J., Sussman, J. B., et al. (2021). Sex differences in cognitive decline among US adults. JAMA Netw. Open 4:e210169.

Lewis, C. R., Talboom, J. S., De Both, M. D., Schmidt, A. M., Naymik, M. A., Håberg, A. K., et al. (2021). Smoking is associated with impaired verbal learning and memory performance in women more than men. Sci. Rep. 11:10248.

Li, G., Shofer, J. B., Petrie, E. C., Yu, C. E., Wilkinson, C. W., Figlewicz, D. P., et al. (2017). Cerebrospinal fluid biomarkers for Alzheimer's and vascular disease vary by age, gender, and APOE genotype in cognitively normal adults. Alzheimers Res. Ther. 9:48.

Lin, K. A., and Doraiswamy, P. M. (2014). When mars versus venus is not a cliché: gender differences in the neurobiology of Alzheimer's disease. Front. Neurol. 5:288. doi: $10.3389 /$ fneur.2014.00288

Lin, Y. F., Smith, A. V., Aspelund, T., Betensky, R. A., Smoller, J. W., Gudnason, V., et al. (2019). Genetic overlap between vascular pathologies and Alzheimer's dementia and potential causal mechanisms. Alzheimers Dement. 15, 65-75. doi: $10.1016 /$ j.jalz.2018.08.002

Lip, G. Y. H., and Kalra, L. (2010). Stroke: secondary prevention. BMJ Clin. Evid. 2010:0207.

Lo Coco, D., Lopez, G., and Corrao, S. (2016). Cognitive impairment and stroke in elderly patients. Vasc. Health Risk Manag. 12, 105-116. doi: 10.2147/vhrm. s75306

Lucca, U., Tettamanti, M., Tiraboschi, P., Logroscino, G., Landi, C., Sacco, L., et al. (2020). Incidence of dementia in the oldest-old and its relationship with age: The Monzino 80-plus population-based study. Alzheimers Dement. 16, 472-481. doi: 10.1016/j.jalz.2019.09.083

Maas, A. H., and Appelman, Y. E. (2010). Gender differences in coronary heart disease. Neth. Heart J. 18, 598-602.

Mackay, J., and Amos, A. (2003). Women and tobacco. Respirology (Carlton, Vic.) $8,123-130$.

Malojcic, B., Giannakopoulos, P., Sorond, F. A., Azevedo, E., Diomedi, M., Oblak, J. P., et al. (2017). Ultrasound and dynamic functional imaging in vascular cognitive impairment and Alzheimer's disease. BMC Med. 15:27. doi: 10.1186/ s12916-017-0799-3

McCarney, R., Warner, J., Fisher, P., and Van Haselen, R. (2003). Homeopathy for dementia. Cochrane Database Syst. Rev. Cd003803.

McKay, E., and Counts, S. E. (2017). Multi-infarct dementia: a historical perspective. Dement. Geriatr. Cogn. Dis. Extra 7, 160-171. doi: 10.1159/ 000470836

Mikkola, T. S., Savolainen-Peltonen, H., Tuomikoski, P., Hoti, F., Vattulainen, P., Gissler, M., et al. (2017). Lower death risk for vascular dementia than for Alzheimer's disease with postmenopausal hormone therapy users. J. Clin. Endocrinol. Metab. 102, 870-877.

Mizuno, T., Mizuta, I., Watanabe-Hosomi, A., Mukai, M., and Koizumi, T. (2020). Clinical and genetic aspects of CADASIL. Front. Aging Neurosci. 12:91. doi: 10.3389/fnagi.2020.00091
Molero, A. E., Pino-Ramírez, G., and Maestre, G. E. (2001). Modulation by age and gender of risk for Alzheimer's disease and vascular dementia associated with the apolipoprotein E-epsilon4 allele in Latin Americans: findings from the maracaibo aging study. Neurosci. Lett. 307, 5-8. doi: 10.1016/s0304-3940(01) 01911-5

Montagne, A., Nation, D. A., Sagare, A. P., Barisano, G., Sweeney, M. D., Chakhoyan, A., et al. (2020). APOE4 leads to blood-brain barrier dysfunction predicting cognitive decline. Nature 581, 71-76. doi: 10.1038/s41586-0202247-3

Nguyen, D. H., Cunningham, J. T., and Sumien, N. (2021). Estrogen receptor involvement in vascular cognitive impairment and vascular dementia pathogenesis and treatment. GeroScience 43, 159-166. doi: 10.1007/s11357020-00263-4

Nimmrich, V., and Eckert, A. (2013). Calcium channel blockers and dementia. Br. J. Pharmacol. 169, 1203-1210.

O'Brien, J. T., and Thomas, A. (2015). Vascular dementia. Lancet (London, England) 386, 1698-1706.

Olivares, D., Deshpande, V. K., Shi, Y., Lahiri, D. K., Greig, N. H., Rogers, J. T., et al. (2012). N-methyl D-aspartate (n.d.) receptor antagonists and memantine treatment for Alzheimer's disease, vascular dementia and Parkinson's disease. Curr. Alzheimer Res. 9, 746-758. doi: 10.2174/156720512801322564

Ornelas, A., Zacharias-Millward, N., Menter, D. G., Davis, J. S., Lichtenberger, L., Hawke, D., et al. (2017). Beyond COX-1: the effects of aspirin on platelet biology and potential mechanisms of chemoprevention. Cancer Metastasis Rev. 36, 289-303. doi: 10.1007/s10555-017-9675-z

Paglieri, C., Bisbocci, D., Di Tullio, M. A., Tomassoni, D., Amenta, F., and Veglio, F. (2004). Arterial hypertension: a cause of cognitive impairment and of vascular dementia. Clin. Exp. hypertens. (New York, N.Y. 1993) 26, 277-285. doi: 10. 1081/ceh-120034134

Pampel, F. C. (2006). Global patterns and determinants of sex differences in smoking. Int. J. Comp. Sociol. 47, 466-487. doi: 10.1177/0020715206070267

Papakonstantinou, E., Bacopoulou, F., Brouzas, D., Megalooikonomou, V., D’Elia, D., Bongcam-Rudloff, E., et al. (2019). NOTCH3 and CADASIL syndrome: a genetic and structural overview. EMBnet.J. 24:e921. doi: 10.14806/ej.24.0.921

Pendlebury, S. T., and Rothwell, P. M. (2009). Prevalence, incidence, and factors associated with pre-stroke and post-stroke dementia: a systematic review and meta-analysis. Lancet Neurol. 8, 1006-1018. doi: 10.1016/s1474-4422(09) 70236- 4

Peng, D. (2019). Clinical practice guideline for cognitive impairment of cerebral small vessel disease. Aging Med. (Milton (N.S.W)) 2, 64-73. doi: 10.1002/agm2. 12073

Pennisi, M., Lanza, G., Cantone, M., D’Amico, E., Fisicaro, F., Puglisi, V., et al. (2020). Acetyl-L-carnitine in dementia and other cognitive disorders: a critical update. Nutrients 12:1389. doi: 10.3390/nu12051389

Persky, R. W., Turtzo, L. C., and McCullough, L. D. (2010). Stroke in women: disparities and outcomes. Curr. Cardiol. Rep. 12, 6-13. doi: 10.1007/s11886009-0080-2

Pimentel, M. L. É (2009). Role of neuropsychological assessment in the differential diagnosis of Alzheimer's disease and vascular dementia. Dement. Neuropsychol. 3, 214-221. doi: 10.1590/s1980-57642009dn30300007

Pinkston, J. B., Alekseeva, N., and González Toledo, E. (2009). Stroke and dementia. Neurol. Res. 31, 824-831.

Podcasy, J. L., and Epperson, C. N. (2016). Considering sex and gender in Alzheimer disease and other dementias. Dialogues Clin. Neurosci. 18, 437-446. doi: $10.31887 /$ dens.2016.18.4/cepperson

Rasmussen, K. L., Tybjærg-Hansen, A., Nordestgaard, B. G., and Frikke-Schmidt, R. (2018). Absolute 10-year risk of dementia by age, sex and APOE genotype: a population-based cohort study. Can. Med. Assoc. J. 190, E1033-E1041.

Reeves, M. J., Bushnell, C. D., Howard, G., Gargano, J. W., Duncan, P. W., Lynch, G., et al. (2008). Sex differences in stroke: epidemiology, clinical presentation, medical care, and outcomes. Lancet Neurol. 7, 915-926. doi: 10.1016/s14744422(08)70193-5

Rizzo, M. R., Fasano, R., and Paolisso, G. (2020). Adiponectin and cognitive decline. Int. J. Mol. Sci. 21:2010. doi: 10.3390/ijms21062010

Robusto-Leitao, O., and Ferreira, H. (2006). Hormones and dementia - a comparative study of hormonal impairment in post-menopausal women, with and without dementia. Neuropsychiatr. Dis. Treat. 2, 199-206. doi: 10.2147/ nedt.2006.2.2.199 
Rocca, W. A., Mielke, M. M., Vemuri, P., and Miller, V. M. (2014). Sex and gender differences in the causes of dementia: a narrative review. Maturitas 79, 196-201. doi: 10.1016/j.maturitas.2014.05.008

Rockwood, K., Bowler, J., Erkinjuntti, T., Hachinski, V., and Wallin, A. (1999). Subtypes of vascular dementia. Alzheimer Dis. Assoc. Disord 13 (Suppl 3), S59-S65.

Rohn, T. T. (2014). Is apolipoprotein E4 an important risk factor for vascular dementia? Int. J. Clin. Exp. Pathol. 7, 3504-3511.

Romàn, G. (2000). Perspectives in the treatment of vascular dementia. Drugs Today (Barcelona, Spain 36, 641-653. doi: 10.1358/dot.2000.36.9.593781

Román, G. (2003). Vascular dementia: a historical background. Int. Psychogeriatr. 15(Suppl. 1), 11-13. doi: 10.1017/s1041610203008901

Rufa, A., De Stefano, N., Dotti, M. T., Bianchi, S., Sicurelli, F., Stromillo, M. L., et al. (2004). Acute unilateral visual loss as the first symptom of cerebral autosomal dominant arteriopathy with subcortical infarcts and leukoencephalopathy. Arch. Neurol. 61, 577-580. doi: 10.1001/archneur.61.4.577

Ruitenberg, A., Ott, A., van Swieten, J. C., Hofman, A., and Breteler, M. M. (2001). Incidence of dementia: does gender make a difference? Neurobiol. Aging 22, 575-580. doi: 10.1016/s0197-4580(01)00231-7

Santabárbara, J., Villagrasa, B., Lopez-Anton, R., De la Cámara, C., GraciaGarcía, P., and Lobo, A. (2020). Anxiety and risk of vascular dementia in an elderly community sample: the role of sex. Brain Sci. 10:265. doi: 10.3390/ brainsci 10050265

Schmitz, M., Hermann, P., Oikonomou, P., Stoeck, K., Ebert, E., Poliakova, T., et al. (2015). Cytokine profiles and the role of cellular prion protein in patients with vascular dementia and vascular encephalopathy. Neurobiol. Aging 36, 2597-2606. doi: 10.1016/j.neurobiolaging.2015.05.013

Shabir, O., Berwick, J., and Francis, S. E. (2018). Neurovascular dysfunction in vascular dementia. Alzheimers and atherosclerosis. BMC Neurosci. 19:62.

Shinoda, M., Fujii, M., Takahashi, O., Kawatsu, A., Uemura, A., and Niimi, Y. (2015). Inverse relationship between coffee consumption and cerebral microbleeds in men, but not women. J. Stroke Cerebrovasc. Dis. 24, 2196-2199. doi: 10.1016/j.jstrokecerebrovasdis.2015.04.032

Sierra, C. (2020). Hypertension and the risk of dementia. Front. Cardiovasc. Med. 7:5. doi: $10.3389 /$ fcvm.2020.00005

Singhal, S., Bevan, S., Barrick, T., Rich, P., and Markus, H. S. (2004). The influence of genetic and cardiovascular risk factors on the CADASIL phenotype. Brain 127, 2031-2038. doi: 10.1093/brain/awh223

Skillbäck, T., Lautner, R., Mattsson, N., Schott, J. M., Skoog, I., Nägga, K., et al. (2018). Apolipoprotein E genotypes and longevity across dementia disorders. Alzheimers Dement. 14, 895-901. doi: 10.1016/j.jalz.2018.02.003

Skoog, I. (1994). Risk factors for vascular dementia: a review. Dementia (Basel, Switzerland) 5, 137-144.

Skoog, I., Hesse, C., Aevarsson, O., Landahl, S., Wahlström, J., Fredman, P., et al. (1998). A population study of apoE genotype at the age of 85: relation to dementia, cerebrovascular disease, and mortality. J. Neurol. Neurosurg. Psychiatry 64, 37-43. doi: 10.1136/jnnp.64.1.37

Sommer, I., Griebler, U., Kien, C., Auer, S., Klerings, I., Hammer, R., et al. (2017). Vitamin D deficiency as a risk factor for dementia: a systematic review and meta-analysis. BMC Geriatr. 17:16. doi: 10.1186/s12877-016-0 405-0

Song, J., Lee, W. T., Park, K. A., and Lee, J. E. (2014). Association between risk factors for vascular dementia and adiponectin. BioMed. Res. Int. 2014, 261672.

Steinberg, M., Hess, K., Corcoran, C., Mielke, M. M., Norton, M., Breitner, J., et al. (2014). Vascular risk factors and neuropsychiatric symptoms in Alzheimer's disease: the Cache County Study. Int. J. Geriatr. Psychiatry 29, 153-159. doi: 10.1002/gps.3980

Sundermann, E. E., Biegon, A., Rubin, L. H., Lipton, R. B., Mowrey, W., Landau, S., et al. (2016a). Better verbal memory in women than men in MCI despite similar levels of hippocampal atrophy. Neurology 86, 1368-1376. doi: 10.1212/ wnl.0000000000002570

Sundermann, E. E., Maki, P. M., Rubin, L. H., Lipton, R. B., Landau, S., and Biegon, A. (2016b). Female advantage in verbal memory: evidence of sex-specific cognitive reserve. Neurology 87, 1916-1924. doi: 10.1212/wnl. 0000000000003288

Tariq, S., and Barber, P. A. (2018). Dementia risk and prevention by targeting modifiable vascular risk factors. J. Neurochem. 144, 565-581. doi: 10.1111/jnc. 14132
Thomas, N. J., Morris, C. M., Scaravilli, F., Johansson, J., Rossor, M., De Lange, R., et al. (2000). Hereditary vascular dementia linked to notch 3 mutations. CADASIL in British families. Ann. N. Y. Acad. Sci. 903, 293-298. doi: 10.1111/ j.1749-6632.2000.tb06379.x

Tomimoto, H. (2011). Subcortical vascular dementia. Neurosci. Res. 71, 193-199.

Treiber, K. A., Lyketsos, C. G., Corcoran, C., Steinberg, M., Norton, M., Green, R. C., et al. (2008). Vascular factors and risk for neuropsychiatric symptoms in Alzheimer's disease: the Cache County Study. Int. Psychogeriatr. 20, 538-553.

van der Steen, J. T., Smaling, H. J., van der Wouden, J. C., Bruinsma, M. S., Scholten, R. J., and Vink, A. C. (2018). Music-based therapeutic interventions for people with dementia. Cochrane Database Syst. Rev. 7:Cd003477.

van Straaten, E. C., Scheltens, P., and Barkhof, F. (2004). MRI and CT in the diagnosis of vascular dementia. J. Neurol. Sci. 226, 9-12. doi: 10.1016/j.jns.2004. 09.003

Venkat, P., Chopp, M., and Chen, J. (2015). Models and mechanisms of vascular dementia. Exp. Neurol. 272, 97-108. doi: 10.1016/j.expneurol.2015.05.006

Vijayan, M., and Reddy, P. H. (2016). Stroke, vascular dementia, and alzheimer's disease: molecular links. J. Alzheimers Dis. JAD 54, 427-443. doi: 10.3233/jad160527

Villa, A., Vegeto, E., Poletti, A., and Maggi, A. (2016). Estrogens, neuroinflammation, and neurodegeneration. Endocrine Rev. 37, 372-402. doi: 10.1210/er.2016-1007

Vinciguerra, L., Lanza, G., Puglisi, V., Fisicaro, F., Pennisi, M., Bella, R., et al. (2020). Update on the neurobiology of vascular cognitive impairment: from lab to clinic. Int. J. Mol. Sci. 21:2977. doi: 10.3390/ijms21082977

Volgman, A. S., Bairey Merz, C. N., Aggarwal, N. T., Bittner, V., Bunch, T. J., Gorelick, P. B., et al. (2019). Sex differences in cardiovascular disease and cognitive impairment: another health disparity for women? J. Am. Heart Assoc. 8:e013154.

Wallin, A., Milos, V., Sjögren, M., Pantoni, L., and Erkinjuntti, T. (2003). Classification and subtypes of vascular dementia. Int. psychogeriatr. 15 Suppl 1, 27-37. doi: 10.1017/s1041610203008937

Wang, X. J., Xu, W., Li, J. Q., Cao, X. P., Tan, L., and Yu, J. T. (2019). Early-life risk factors for dementia and cognitive impairment in later life: a systematic review and meta-analysis. J. Alzheimers Dis. JAD 67, 221-229. doi: 10.3233/jad-180856

Warner, T. D., Nylander, S., and Whatling, C. (2011). Anti-platelet therapy: cyclooxygenase inhibition and the use of aspirin with particular regard to dual anti-platelet therapy. Br. J. Clin. Pharmacol. 72, 619-633. doi: 10.1111/j.13652125.2011.03943.x

Whitmer, R. A., Gunderson, E. P., Quesenberry, C. P. Jr., Zhou, J., and Yaffe, K. (2007). Body mass index in midlife and risk of Alzheimer disease and vascular dementia. Curr. Alzheimer Res. 4, 103-109. doi: 10.2174/156720507780362047

Winstein, C. J., Stein, J., Arena, R., Bates, B., Cherney, L. R., Cramer, S. C., et al. (2016). Guidelines for adult stroke rehabilitation and recovery: a guideline for healthcare professionals from the american heart association/american stroke association. Stroke 47, e98-e169.

Wise, A. L., Gyi, L., and Manolio, T. A. (2013). eXclusion: toward integrating the $\mathrm{X}$ chromosome in genome-wide association analyses. Am. J. Hum. Genet. 92, 643-647. doi: 10.1016/j.ajhg.2013.03.017

Wu, C. Y., Hu, H. Y., Chow, L. H., Chou, Y. J., Huang, N., Wang, P. N., et al. (2015). The effects of anti-dementia and nootropic treatments on the mortality of patients with dementia: a population-based cohort study in Taiwan. PLoS One 10:e0130993. doi: 10.1371/journal.pone.0130993

Xing, Y., Qin, W., Li, F., Jia, X. F., and Jia, J. (2013). Associations between sex hormones and cognitive and neuropsychiatric manifestations in vascular dementia (VaD). Arch. Gerontol. Geriatr. 56, 85-90. doi: 10.1016/j.archger. 2012.10.003

Yaffe, K., Sawaya, G., Lieberburg, I., and Grady, D. (1998). Estrogen therapy in postmenopausal women: effects on cognitive function and dementia. JAMA 279, 688-695. doi: 10.1001/jama.279.9.688

Yamada, M., Mimori, Y., Kasagi, F., Miyachi, T., Ohshita, T., Sudoh, S., et al. (2008). Incidence of dementia, Alzheimer disease, and vascular dementia in a Japanese population: radiation effects research foundation adult health study. Neuroepidemiology 30, 152-160. doi: 10.1159/000122332

Yang, H. D., Kim, D. H., Lee, S. B., and Young, L. D. (2016). History of Alzheimer's Disease. Dement. Neurocogn. Disorders 15, 115-121.

Yaowaluk, T., Senanarong, V., Limwongse, C., Boonprasert, R., and Kijsanayotin, P. (2019). Influence of CYP2D6, CYP3A5, ABCB1, APOE polymorphisms and 
nongenetic factors on donepezil treatment in patients with Alzheimer's disease and vascular dementia. Pharmacogenomics Pers. Med. 12, 209-224. doi: 10. 2147/pgpm.s211259

Zekry, D., Hauw, J. J., and Gold, G. (2002). Mixed dementia: epidemiology, diagnosis, and treatment. J. Am. Geriatr. Soc. 50, 1431-1438. doi: 10.1046/j. 1532-5415.2002.50367.x

Zhong, G., Wang, Y., Zhang, Y., Guo, J. J., and Zhao, Y. (2015). Smoking is associated with an increased risk of dementia: a metaanalysis of prospective cohort studies with investigation of potential effect modifiers. PLoS One 10:e0118333. doi: 10.1371/journal.pone.011 8333

Zhu, W., Wang, X. R., Du, S. Q., Yan, C. Q., Yang, N. N., Lin, L. L., et al. (2018). Anti-oxidative and anti-apoptotic effects of acupuncture: role of thioredoxin-1 in the hippocampus of vascular dementia rats. Neuroscience 379, 281-291. doi: 10.1016/j.neuroscience.2018.03.029

Zucchella, C., Sinforiani, E., Tamburin, S., Federico, A., Mantovani, E., Bernini, S., et al. (2018). The multidisciplinary approach to Alzheimer's disease and dementia. a narrative review of non-pharmacological treatment. Front. Neurol. 9:1058. doi: 10.3389/fneur.2018.01058
Author Disclaimer: The content is solely the responsibility of the authors and does not necessarily represent the official views of the National Institutes of Health.

Conflict of Interest: The authors declare that the research was conducted in the absence of any commercial or financial relationships that could be construed as a potential conflict of interest.

Publisher's Note: All claims expressed in this article are solely those of the authors and do not necessarily represent those of their affiliated organizations, or those of the publisher, the editors and the reviewers. Any product that may be evaluated in this article, or claim that may be made by its manufacturer, is not guaranteed or endorsed by the publisher.

Copyright (c) 2021 Akhter, Persaud, Zaokari, Zhao and Zhu. This is an open-access article distributed under the terms of the Creative Commons Attribution License (CC BY). The use, distribution or reproduction in other forums is permitted, provided the original author(s) and the copyright owner(s) are credited and that the original publication in this journal is cited, in accordance with accepted academic practice. No use, distribution or reproduction is permitted which does not comply with these terms. 